\title{
Pribatizazioa ala (auto)kudeaketa komunitarioa? Euskadiko gizarte- zerbitzuen izaera mistoa eztabaidagai
}

\section{Enekoitz Etxezarreta Etxarri}

Ekonomia Aplikatua I Saila, GEZKI-Gizarte Ekonomia

eta Zuzenbide Kooperatiboko Institutua, Euskal Herriko Unibertsitatea UPV/EHU

<enekoitz.etxezarreta@ehu.es>

\section{Mikel Zurbano Irizar}

Ekonomia Aplikatua I Saila, GEZKI-Gizarte Ekonomia

eta Zuzenbide Kooperatiboko Institutua, Euskal Herriko Unibertsitatea UPV/EHU

\section{Baleren Bakaikoa Azurmendi}

Ekonomia Aplikatua I Saila, GEZKI-Gizarte Ekonomia

eta Zuzenbide Kooperatiboko Institutua, Euskal Herriko Unibertsitatea UPV/EHU

Jarraian jorratzen dugun artikuluan Gizarte Zerbitzuen Euskal Sistemaren osaeran funtsezkoa den gai bat aztertzen da: zerbitzu horien hornidura publiko edo pribatuaren afera, hain zuzen ere. Artikuluak egungo egoera aztertu baino, egun mahai gainean dauden aukera eta eredu ezberdinen eztabaida jorratzen du, horien aldeko eta aurkako argudioak jasoz eta horien gainean egileek duten iritzia azalduz. Horretarako lehen lehenik, bai literatura espezializatuaren aldetik eta baita sektorean eragiten duten arautegi ezberdinen bitartez ere, gizarte-zerbitzuen sistemaren eredua definitzen duten ezaugarri nagusiak aztertzen dira. Bigarren urrats batean, ezaugarri horien inguruan sektoreko zenbait pertsona adituk duten iritzia jasotzen da, horien diskurtsoak jaso eta landuz hiru galdera nagusiren inguruan: Euskadiko ongizateerregimenaren analisia batetik, gizarte-zerbitzuen sistema mistoaren definizioa bestetik eta zeharkako kudeaketaren definizioa eta aplikazioa azkenik. Azken kapitulu batean, artikulu honen egileok, planteaturiko eztabaida nagusien inguruan dugun iritzia plazaratu nahi izan dugu, eztabaidarako ekarpen gehigarri gisa baliagarri izan litekeenaren esperantzan.

\section{HITZ GAKOAK:}

ongizate-erregimena, ongizate mistoa, Gizarte Zerbitzuen Euskal Sistema, hirugarren sektorea, Mendekotasun Legea.
Este artículo trata un tema fundamental en la configuración del Sistema Vasco de Servicios Sociales: el carácter público o privado de la provisión de dichos servicios. Más que ofrecer un diagnóstico de la situación actual, intenta presentar los principales modelos y opciones a debate, reproduciendo los argumentos favorables y contrarios a cada modelo. Para ello, en primer lugar estudia, tanto desde la literatura especializada como desde el marco normativo, los principales elementos que caracterizan el sistema de los servicios sociales a nivel estatal y en Euskadi. En un segundo apartado, se desarrolla un análisis cualitativo de los discursos de varios expertos del sector, centrados en los tres temas principales teorizados previamente: la definición del régimen de bienestar de Euskadi, la definición del sistema mixto de servicios sociales, y la definición y aplicación de la provisión indirecta de estos servicios. Para terminar, los autores del artículo nos posicionamos respecto a esos temas, a fin de realizar una aportación académica al debate.

\section{PALABRAs ClaVe:}

régimen de bienestar, bienestar mixto, Sistema Vasco de Servicios Sociales, tercer sector, Ley de Dependencia. 


\section{Sarrera}

Egungo krisi ekonomikoaren testuinguruak, eta honek finantzaketa publikoarengan ezarritako presio izugarriak, lehen planora ekarri du berriz ere gizartezerbitzuen iraunkortasun ekonomikoaren afera. Non eta gainera, bere benetako neurrira urrundik ere iristea lortu ez duen esparru batean, gizarte-zerbitzuen esparruan, honen garapena zinez berankorra eta heldu gabea baita oraindik orain. Sistemaren sendotzea erdietsi aurretik, murrizketa politikak planteatzeak atzerapauso larri gisa kontsideratuak izaten ari dira sektoreko profesional eta gizarte-eragile eta arduradun politikoen aldetik. Egia da, halaber, krisi testuinguruak izan ohi direla egokienak, erakunde ezberdinek harturiko inertzia eta joera ez-eraginkor ezberdinak birplanteatzeko ere.

Testuinguru honetan planteatzen dugu guk, batzuren begitan nahikoa errepikatua eta errepikakorra suerta litekeen eztabaida hau, hots, gizarte-zerbitzuen izaera publiko-pribatuaren eztabaida, hain zuzen ere. Argi utzi nahi genuke, hastapenetik, eztabaida hau bi ikuspegi ezberdinetatik abiatu daitekeela: bata oportunista, pribatizazioa (krisiari aurre egiteko) estrategia ekonomiko (koiuntural) gisa planteatzen duena eta bestea ideologikoagoa, pribatizazioa eredu desiragarri gisa ulertzen duena. Bi ikuspegi ezberdin dira gure iritzian, nahiz eta nahasian agertu ohi diren, are gehiago krisi ekonomiko larriko egoera batean.

Pribatizazioa eredu desiragarri gisa ulertzen dutenek, ontasun zein krisialdi ekonomiko testuinguruan planteatu izan dute eredu hori, funtsean premisa liberaletan oinarritzen dena: ezein sektorek baliabideen esleipen eraginkorragoa egiten du merkatuko lehia baldintzak ahalbidetuz gero, hots, eskaintzaren aldetik hornitzaile kopuru esanguratsu bat lehian, eta eskariaren aldetik, aukeratzeko aukera duen erabiltzaile/kontsumitzaile kaudimendun bat ezarriz, hain zuzen ere.

Euskadiko gizarte-zerbitzuen testuinguruan inork gutxik planteatu izan du sektorearen garapena arestian aipaturiko premisa horien ildotik. Gure testuinguruan, ereduaren inguruko eztabaida gertutasunezko eredu komunitarioaren klabean egin izan da. Eredu honetan, sektore publiko indartsua eta mozkinez besteko erakundeen arteko lankidetza da, teorian, jorratu nahi den eredua. Hargatik, eztabaida eskaintza publiko nahikoa eta kalitatezkoa lortzea eta hori eutsi ahal izango duen finantzazio mekanismo eraginkorra diseinatzearen bidetik joan izan da.

Baina eztabaidaren giltzarri nagusiak horiek izanik ere, ezin ezkutatuko dugu azken hamarkadan erakunde pribatu kapitalisten sarrera bizkor bat bizi izan dugula. Esparru batzuetan beste batzuetan baino nabarmenagoa izan den arren, azken hamarkadan geroz eta hornikuntza esparru zabalagoak (azpi) kontratatu dira enpresa pribatuen mesedetan. Prozesu honek gogoeta sakon bat eskatzen duela iruditzen zaigu, bai termino ekonomikotan eta baita eredu desiragarriari dagokionean ere. Galderak oso modu sinplean formula litezke: merkeagoa al da, benetan, erakunde pribatuen bidez emaniko eskaintza? Eta hala bada, zeren kontura da merkeagoa? Eta harago joanez, ze ondorio dakartza honek sistemaren koordinazio eraginkorra ezartzeko, erakunde publikoen kudeaketa ahalmenari begira, eta (azken finean galdera nagusia behar lukeena) behar duen orok kalitatezko zerbitzua jasotzeko aukera izan dezan?

Galdera horiek erantzuten ahaleginduko gara jarraian garatzen dugun artikuluan. Lehen lehenik, marko teoriko orokorretik abiatuko gara, gizarte-zerbitzuen garapenaren eta ereduaren gaineko hurbilketa teoriko bat proposatuz. Bigarrenik, Euskadiko testuinguruan eragiten duten lege ezberdinek bultzatu asmo duten ereduaren nondik norakoak finkatuko ditugu. Eta azkenik, gai honek planteatzen dituen galdera ezberdinen inguruan sektoreko zenbait aditurekin izaniko elkarrizketetatik ateratako pasarte nagusiak aurkeztuko dira. Artikulua ikerketa honetatik eratorritako ondorio nagusiekin itxiko da.

Metodologikoki, beraz, gaiaren inguruko literatura espezializatua da lehenik jorratu dena. Gure gizartezerbitzuen eredua aztertzen duten zenbait egileren testuak landu dira, oinarri nagusiak finkatzeko helburuz. Bigarrenik, gizarte-zerbitzuen araudiaren gaineko eguneratzea proposatu da, legalki sistema nola artikulatzen joan den ikusteko. Artikulu honetan, halaber, izaera kualitatiboko analisia jorratu da, sektorean arituak eta adituak diren pertsonen diskurtsoak landuz eta gaika ordenatuz. Elkarrizketak Gipuzkoako gizarte-zerbitzuetako arduradunekin burutu dira, eta diskurtso ezberdinen arteko elkarrizketa bat irudikatzea izan dugu helburu, posizionamendu ideologiko ezberdinak aurka jarriz eta horien aurrean gure iritzia finkatuz. Ondorio itxiak ezartzea baino, eztabaidarako zenbait oinarri proposatzea baino ez da artikulu honen xedea.

\section{Hurbilketa teorikoa: Euskadiko ongizate-erregimena}

\subsection{Gizarte Zerbitzuen bilakaera orokorra: publifikaziotik pribatizaziora}

Gizarte-zerbitzuen bilakabidearen inguruko bi irakurketa osagarrirekin abiatuko gara. Bilakabide honen lehen urratsak Espainian ongintzazko elkarte erlijiosoetan oinarrituriko karitatezko hornikuntza sistema batetik gizarte-zerbitzuen sare publiko batera igarotzeko ahaleginean ardaztu dira.

Roldán eta García-k (2006) prozesu honen berrikuspen interesgarria burutzen dute, gizarte-zerbitzuen egituratzea aztertzen dutelarik eragile publiko eta pribatuen aro ezberdinetan mantenduriko oreka ezberdinen ikuspegitik. Honela, egileon iritzian honako aro hauek bereiz litezke Gizarte Zerbitzu espainiarren sare publikoaren osatze prozesuan:

- Frankismoaren azken urteak (1960-1978): aro honetan Europako herrialde demokratiko ezberdi- 
nak ongizate-estatuaren ezarpenean diharduten bitartean, Espainian erregimen frankistak familia bultzatzen du norbanakoen gizarte-beharrizanak asetzeko instituzio nagusi gisa. Are gehiago, frankismo garaian indar handiz mantendu zen subsidiariotasunaren ideia, familiaren zentraltasuna indartzeaz batera eliza katolikoak bereganatzen zuelarik zerbitzuen hornikuntza ia osoa. Erregimen frankistaren baitan ordea barne mugimenduak sortzen joan ziren bai elizaren baitan (Cáritas edo Juventudes Obreras Católicas bezalako mugimenduen bidez) bai eta auzoelkarteen ekimenez, ongintzazko sistema karitatetsu honetatik apurka-apurka 'gizarte-laguntza' bezalako adierak sartzen joateko.

- Trantsizio politikoko aroa (1978-1982): trantsizio politikoarekin batera bi gizarte-prozesu eman ziren aldi berean: elizari loturiko ongintzazko/ karitatezko erakundeen gutxiespen soziala alde batetik eta frankismo berantiarrean sorturiko gizarte-mugimenduen krisia, bestalde, mugimendu horietako lider ugari administrazio publikoetara igaro baitziren. Prozesu horiek gizarte-zerbitzuen sistema publiko baten ezarpenaren aldeko mugimendua sortu zuten, 1978ko Konstituzioaren izpirituak bultzatuta aldi berean, udal guztietan gizarte-ongizateari loturiko egitura administratibo berriak sortu ziren, eta gizartelangintzari loturiko profesional berriak kontratatzen hasi ziren langile publiko gisa. Sistemaren publikotze saio honek gizarte-mugimendu laikoen desaktibazioa ere ekarri zuen neurri batean, baita ongintzazko elkarte erlijiosoen urruntze bat ere herri erakundeekiko (nahiz eta azken horiek beren ongintzazko zerbitzuetan jarraitu).

- Gizarte-zerbitzuen garapen aroa (1982-1990): Gizarte Zerbitzuen eredu publikoaren ezarpena gauzatu zen, 1978ko Konstituzioak ezarritako lurralde-deszentralizazioan sakonduz, Autonomia Erkidego eta udalerriek lehen mailako protagonismoa eskuratu zuten. Hamarkada honetan bi etapa ezberdin ere nabarmendu litezke:

- 1982-1986 urtealdia, non Autonomia Erkidegoetako Gizarte Zerbitzuen legeak onartu baitziren ikuspegi oso estatalista batekin eta elkarte laikoen garapen mugatuarekin.

- 1987-1990 urtealdia, non gizarte-zerbitzuen udal-sare publiko baten proposamena gauzatu baitzen, batik bat 1988ko Hitzartutako Planaren eraginez (Plan Concertado de Prestaciones Básicas de Servicios Sociales en las Corporaciones Locales) ${ }^{1}$.

Roldán eta García-ren (2006) irudiko, hortaz, 6oko hastapenetatik goeko amaierara arte gizartezerbitzuen sare publikoa sortzen joatea izan zen bilakabidearen ardatz nagusietako bat. Adelantado eta Jiménez (2003) bat datoz puntu honetan, horien iritzian epealdi honetan ezker politikoaren kulturan

${ }^{1}$ Euskadin ez zen Hitzartutako Plana sinatu, Kontzertu Ekonomikoaren ondorioz kupo bidezko finantzazio mekanismo propioa izateak ez baitzuen hartara behartzen (Casado, 2007). nozio partekatua baitzen gizarte-zerbitzu unibertsal, publiko eta tokiko mailakoen egokitasuna. Argudio horiek, ongintzazko irizpide asistentzialen aurkakoak ziren, nahiz eta nolabaiteko elkarbizitza mantendu sektore horiekin, elkarte erlijiosoak mantendu egin baitziren beren zerbitzu hornitzaile funtziotan.

Rodríguez Cabrero-k (2004) nabarmentzen du, ordea, lehen une batean sistemak bere publikotasunerantz jo zuen arren, goeko hamarkadatik aurrera, eta lege autonomikoen garapenaren eskutik, sistema misto bezala egituratzen joan dela. 9oeko hamarkadaren hastapenetan, hortaz, kontsolidazio erlatiboko aroa etorri zen, zerbitzu publikoen sare zabal baten hedapena ematen hasi baitzen, baina aldi berean ereduaren berrikuspen kritikoa gauzatu zen, sorturiko gizarte-beharrizan eta gizarte-bazterketa fenomeno berrien aurrean gizarte-zerbitzuek azalduriko erantzuteko ahalmen mugatuak bultzatuta eta gizartelangileen lan profesionalaren birplanteamenduaren ondorio. Aro honetan bertan hasi ziren gizarteekintzako elkarte zein enpresa pribatu ezberdinak gizarte-zerbitzu berrien eskaintzan sartzen (esaterako etxez-etxeko laguntza zerbitzuetan).

2000. urtetik hona zabaldu da azken aro bat, non beharrean aurkitzen diren gizarte-talde berrien presioak eraginda, mahai gainean jarri baita zenbait oinarrizko gizarte-prestazio unibertsal bilakatzeko premia, gizarte-zerbitzuen ohiko izaera asistentziala gaindituz. Unibertsaltasuneranzko apustu honek gizarte-zerbitzuen sistema gainerako sistema unibertsalekin parekatzea bilatu du. Era berean, aurreko hamarkadan agertzen hasitako fenomenoaren orokortzea eman da, hau da, elkarte boluntarioek, enpresa pribatuek eta estatuak partekaturiko zerbitzuen hornikuntzarako sistema mistoaren hedapena, alegia (Rodríguez Cabrero, 2004).

Badirudi beraz, 9oeko hamarkadak sistema publiko bihurtze bidean inflexio puntu bat ekarri zuela. Adelantado eta Jiménez-ek (2003) joera aldaketa hau urte horietan emandako tesi neoliberalen garaipenaren testuinguruan interpretatzen dute. Tesi neoliberal horien aplikazioa gizarte-politiken esparruan bi ardatz nagusitan mamitu da: gastu publikoaren euspena alde batetik eta zerbitzuen zuzeneko hornikuntzari muzin egitea bestetik. Bi joera aldaketa horiek abagune berria sortu dute ekimen pribatuarentzat, ongintzazko elkarteek, maila komunitarioko ekimenek eta batik bat enpresa pribatu merkantilek beren posizioa berrindartua ikusi dutelarik (Sarasa, 2000).

'Bir-merkantilizazio' neurri horiek bide ezberdinetatik planteatzen ari dira: lehenik, arestian aipatu dugun enpresa pribatuen sarreraren eskutik, hornitzaile ordezko edo osagarriak bilakatuz; bigarrenik, erabiltzaileen ordainketa-sistema osagarrien bidetik, zerbitzu publikoen dohaintasunean atzera eginez; eta hirugarrenik, prestazio ekonomiko nagusien (pentsio eta desenplegu laguntzak) oinarrian kontribuziosistemak mantentzeagatik, sistema horiek publikoak izanagatik ez baitute inola ere lan merkatuko disparekotasunik konpontzen, are gehiago, lan merkatuak 
sorturiko gizarte-desberdintasunak areagotu baino ez baitituzte egiten (Noguera, 2000).

Politika horien ondorioz interpreta daiteke beraz, merkatuko mekanismoen barneratze bat eman dela gizarte-politiketan, horrek orain arte finkatzen joandako ongizate-erregimenaren 'bir-merkantilizatzean' (re-commodification) (Esping-Andersen, 1999) sakontzea ekarri duelarik, nahiz eta inork gutxik defendatuko duen sistemaren guztizko pribatizazio bat eman denik (Noguera, 2000; Rodríguez Cabrero, 2004; Del Pino eta Ramos, 2009). 'Bir-merkantilizatzearen' ildoan sakontzeak, espainiar erregimena planteamendu kontserbadore/unibertsalistetatik planteamendu asistentzialistetarantz desplazatu du (Noguera, 2000), eta horren ondorioz, ongizateerregimen ezberdinen ezaugarrien nahasketa bat da Espainiak gaur-gaurkoz azaltzen duen eredua.

\subsection{Espainiako ongizate-erregimenaren analisia}

Honela, lehen gerturapen bat egiteko, espainiar ongizate-estatuak errenten bermerako mekanismo bismarckiarrak eta estaldura unibertsaleko planteamendu beveridgearrak uztartzen dituela ondorioztatzen du Moreno-k (2009), paradoxikoki gizarte-eskubideen unibertsaltasuna gizarte-babesera bideraturiko zenbait prestazioren murrizketarekin batera eman delarik.

Noguera-ren (2000) iritzian ere, Espainian, Europan zehar identifikaturiko hiru erregimenen ezaugarriak agertzen dira nahasian: eredu unibertsal/sozialdemokratako programekin batera (osasuna eta hezkuntza), eredu kontinental/kontserbadoreko elementu sendoak ere agertzen dira (kontribuzio bidez finantzaturiko pentsio eta desenplegu diru laguntzak), eta baita eredu asistentzial/liberaleko zenbait aparteko prestazio ere (prestazio ez-kontributiboak, gizarteratzeko gutxieneko errentak, gizartezerbitzuak, lan merkatuko desarautzeak, etab.).

Hiru eredu horien gainezarpenak sekuentzia historiko argi bati erantzuten diola gehitzen du, gainera: lehen aro aurre-demokratikoan neurri kontserbadoreak nagusitu ziren, trantsizioko aroan planteamendu sozialdemokratak indartu ziren eta azken bi hamarkadetan jite liberaleko ildoen hedapen progresibo batean murgilduak gara. Egile beraren ustez eredu liberal/asistentzial baterantz gerturatzen gaituzten neurriak nagusitzen ari dira bai osasun arloan, bai lan merkatuan, eta bai pentsio edo desenplegurako programetan ere (Noguera, 2000). Hala ere, espainiar ongizate-estatuaren 'asistentzializazio' prozesu bat ematen ari dela modu kategorikoan baieztatu beharrean, egile honek dualizazio prozesu baten kontzepzioa hobesten du: zatiketa gero eta argiagoa ematen ari da lan merkatuan integratutako biztanleen (zeintzuk gizarte-babes publiko indartsu bat gozatzen duten kontribuzio-erregimenen bitartez) eta lan merkatutik at geratu diren gainerako biztanle prekarizatu eta gizarte-babes publikorik gabekoen artean.

Gallego, Gomà eta Subirats-en (2003) iritzian, egun antzematen den ezaugarri nahasketa hori Espainian emandako garapen berankorrari zor zaio, ongizateestatu keynesiarraren eraketa prozesua eta berreraketa prozesua une historiko berean gainezarri izanaren ondorio, alegia. Egileon iritzian, eraketa prozesu hori berandu hasi izanak (1975-1985 epealdian, hain zuzen) espainiar ongizate-sistemaren zabaltzea eta hedapena beste testuinguru sozioekonomiko batean egitea ekarri du, eta hargatik antzematen dira eraketa prozesuko zenbait joera (unibertsaltasuna, sare publikoaren hedapena, etab.) berreraketa prozesuko beste zenbait joerekin gainezarriak (defizit publikoaren kontrola, kudeaketa pribatuaren hazkundea, etab.).

Hiru eredu europarren nahasketaz gain, beste hiru ezaugarri nabarmentzen ditu Moreno-k (2009) espainiar sistemaren bereizgarri gisa: lehena, gizartepolitiken egitura deszentralizatua, bai politika publikoen diseinuan eta baita aplikazioan ere; bigarrena, elkartegintzako erakundeen parte hartzea zerbitzuen hornikuntzan, welfare mix ereduko sistema egikaritzen ari delarik; eta hirugarrena familiaren (eta zehazkiago, emakumeen) esku hartze zabala gizarte-politiken esparru guztietan, zeinak baliabide familiarren gain-ustiatzean eta "superemakumeetan" oinarrituriko eredu batean ezarpena ekarri baitu (Moreno, 2002).

Ereduaren izaera familiarista nabarmentzen da besteen gainetik, Espainian betidanik izan baitu familiak zentraltasun argi bat ez estatuak ez merkatuak ase ez dituen ongizate-zerbitzuen estalduran. Are larriagoa dena, 'gizarte-arrisku berrien' testuinguruan, estatuak ez du emakumeak orain arte bete dituen eta apurka-apurka betetzeari utzi behar liokeen zerbitzu horien hutsunea betetzeko estaldura publiko nahikorik finkatu eta paradoxikoki beharrizan berri horiei erantzuteko "ber-familiartze" joeran kokatzen diren politikak jarri ditu abian (Noguera, 2000; Pérez Orozco, 2006), super-emakumeen errealitatea sortuz: etxeko ardurak albo batera ez uzteaz gain lanmerkatuko betebeharrei erantzun behar dien emakumearen figura, alegia (Moreno, 2002).

\subsection{Euskadiko Gizarte Zerbitzuen ongizate- erregimen autonomikoa}

Nazioarte mailako ongizate-sistemak sailkatzeko ongizate-erregimenen analisiak proposatzen dituen aldagaiak berdin aplika litezke estatuz azpiko ongizate-sistemak aztertzeko ere. Horretara dator Gallego, Gomà eta Subirats-ek (2003) proposaturiko “ongizate-erregimen autonomikoen" analisia.

Euskadiko gizarte-zerbitzuen alorra aztergai dugularik, egile horien analisiak zerbitzu horietan lau gizarte-egitura nagusiek (estatuak, merkatuak, familiak eta komunitateak) zein proportziotan parte hartzen duten jaso nahi du. Azken emaitza bi aldagai ezberdinen gurutzaketatik lortzen da: alde batetik erkidegoen analisia legoke, non aztertzen baita bataz beste, hau da ongizate-zerbitzu guztiak kontuan hartuz, autonomia erkidego bakoitzean zein gizarte-egiturak duen pisu handiagoa; beste aldetik 
ongizate-zerbitzu konkretu bakoitzari egokitutako analisi bera egiten da, kasu honetan bataz bestekoa aztertzen diren zazpi autonomia erkidegoen datuak batuz lortzen delarik: Euskadi, Nafarroa, Katalunia, Balentziar Erkidegoa, Galizia, Kanariar Uharteak, eta Andaluzia.

Has gaitezen lehen emaitzatik. Azterturiko zazpi autonomia erkidegotako gizarte-politiken esparruak modu honetan kokatuko lirateke:

1. Irudia. Ongizate-erregimen autonomikoak gizartepolitiken esparruen arabera

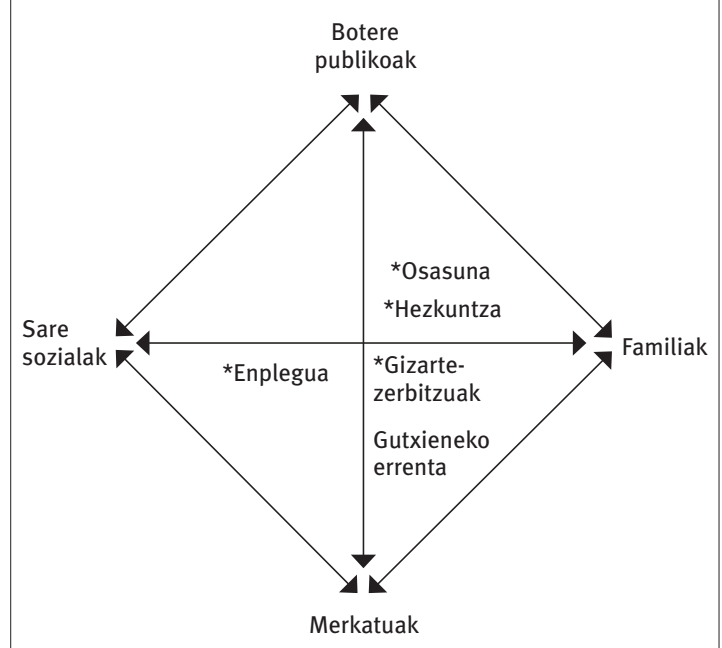

Iturria: Gallego, Gomà eta Subirats, 2003: 227.

Analisia beti ere gizarte-zerbitzuen esparrura bideratuz, ondorioztatzen dute Espainia mailan, azterturiko zazpi erkidegoak erkatuz, gizarte-zerbitzuen erantzukizuna nagusiki familia esparrua eta merkatuko eragileen artean banatzen dela, esparru publikoaren esku hartzearen ahultasunak eraginda neurri handi batean. Gizarte-zerbitzuena, beraz, bere garapenean bilaturiko sare publikoaren ideiatik nahiko urrun geratu dela ondorioztatuko genuke, nahiz eta Euskadiren kasuan bestelako dinamikarik ere ageri den.

Analisi eskema bera Autonomia Erkidegoen esparrura eramanez, Euskadiren erregimena definitzen duten bi erpin nagusiak sektore publikoa eta gizarte-sareak direla ondorioztatzen dute egileok. Euskadiren azken urtetako gizarte-politiken ezaugarri nagusien artean bi leudeke, hortaz: alde batetik sektore publikoaren parte hartze hazkor eta garrantzitsua eta beste aldetik elkartegintzazko ehun indartsu eta dinamiko bat, bai herri erakundeetatik bertatik bultzatuta baina baita gizarte-ekimenaren bitartez abiarazia ere.

Azken bi emaitza horiek gurutzatuz espero izateko da, beraz, gure erkidegoan gizarte-zerbitzuen sistema benetan egituraketa konplexuko sistema bat izatea, bi tradizio ezberdinen uztarketatik egonkortuz

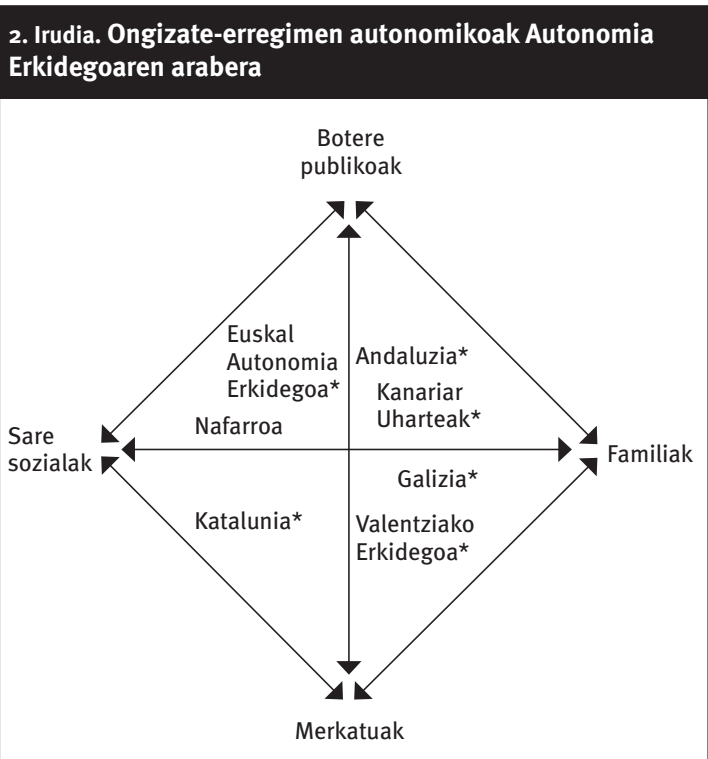

Iturria: Gallego, Gomà eta Subirats, 2003: 227.

joango baita bertoko eredua: alde batetik Euskadin (baita Nafarroan ere) inon baino nabarmenagoa den tradizio publiko eta komunitario sendo bat eta bestalde, gizarte-zerbitzuetan nagusitasunezko papera jokatzen duten erakunde pribatu eta informalen presentzia garrantzitsua.

\section{Hurbilketa normatiboa: izaera mistoaren aitortza}

Orain arte garaturiko eztabaida teorikoak lege esparruan zer nolako isla izan duten aztertuko dugu jarraian, gizarte-zerbitzuen esparruan azken hamarkadan berebiziko eragina izan duten bi lege nagusi aztertuz: Norberaren Autonomia Sustatzeko eta Mendetasun egoerako Pertsonei Laguntza Emateko abenduaren 14ko 39/2006 Legea, edo laburrago eta hizkera arruntean esanda, Mendekotasun Legea, batetik eta Euskadiko 12/2008 Gizarte Zerbitzuen Legea, bestalde. Euskadi mailan onartu zen hirugarren lege bat, 18/2008 Gizarteratzeko eta Diru Sarrerak Bermatzeko Legea hain zuzen ere, gizartezerbitzuen garapenean eragina izaten ari dena, baina egituraketa mistoaren eztabaidan, gure iritziz, sakoneko eztabaidarik planteatzen ez duenez, ez da beronen analisi zehatzik egingo.

\subsection{Mendekotasun legea}

'Mendekotasun Legeak' 3. artikuluan “izaera publikoa” ezartzen badu ere printzipio gisa, gero zerbitzuen hornikuntza bideratzea ez du sare publikoaren egiteko esklusibo gisa jasotzen Honela, 'Mendekotasun Legea' egikaritzeko ezartzen den sistemak, herri erakundeen parte hartze eta lankidetzarako markoa ezartzen du, horien arteko koordinaziorako organoak 
sortuz (nagusiki Lurralde Kontseilua), baina ez du baieztatu sistema honek hertsiki publikoa izan behar duenik. Honela, sistemak berak "eskuragarri dauden baliabide publiko eta pribatuen hoberenatzea" (IVAP, 39/2006 Legea: 5) bilatuko duela aitortzen duen unetik bertatik, sistema misto baten aldeko hautuan sakontzen jarraitzen du.

Ondorioz, ekimen pribatuaren parte hartzeari zuzeneko aipamena egiten zaio legearen artikulatu ezberdinetan, nagusiki gizarte-ekimeneko eragileei erreparatuz. Zioen azalpenean bertan, hirugarren sektoreak historikoki suposatu duenari aitorpena egiten zaio:

\section{[...] ez dago zalantzan jartzerik hirugarren sektoreko erakundeak (gizarte-zerbitzuen arloan dihardutenak) aspalditik ari direla lanean men- detasunen bat dutenei laguntzeko, eta familiek eta tokiko erakundeek arlo horretan egiten duten lanari bultzada ematen. Erakunde horiek sare sozial zabala osatu dute mendetasunen bat jasaten dutenak gizarte-bereizkeria izateko duten arriskutik babesteko (IVAP, 39/2006 Legea: 5).}

Era berean, legearen 16. artikuluko 2. puntuan, sistema osatzen duten zentro publiko eta pribatu itunduez diharduenean, hirugarren sektoreko erakundeei lehentasuna ematen zaie gainerako ekimen pribatuko eragileen aurrean:

\section{[...] hitzartutako zentro pribatuen erregimen juridikoa eta jarduteko baldintzak autonomia- erkidegoek zehaztuko dituzte. Sarean sartzerakoan, arreta berezia jarriko da hirugarren sektorearekin zerikusia dutenetan (IVAP, 39/2006 Legea: 24).}

Artikulu bereko 4. puntuan, berriz ere, hirugarren sektorearen aipamena egiten da, ez hainbeste aurreko puntuan onartzen zaion hornitzaile funtzioa kontuan hartuz, baizik eta bere advocacy funtzioa aintzat hartuz:

\section{[...] herritarrek mendetasuna duten pertsonekiko elkartasunezko lankidetza izan dezatela sustatuko dute aginte publikoek, hain zuzen ere boluntarioen elkarteen eta hirugarren sektoreko elkarteen parte hartzearen bidez (IVAP, 39/2006 Legea: 24)².}

\subsection{Euskadiko $12 / 2008$ Gizarte Zerbitzuen legea}

Lege honek gizarte-zerbitzuen sistemaren egituraketa zehazterako orduan azken alor bat ekimen pribatuaren esku hartzea erregulatzeko garatzen du (V. Titulua). Oro har, legeak zerbitzuak eskaintzeko lau modu aurreikusten ditu: zuzeneko kudeaketa, itunak (legean aurreikusitako itun-araubidearen menpe), zeharkako kudeaketa (Administrazio

2 Alabaina, hirugarren sektoreko erakundeez gain, bestelako eragile pribatuen parte hartzea ere kontuan hartzen du Legeak, adibidez 3. artikuluak legearen printzipioak ezartzen dituenean m) azpiatalean.
Publikoaren kontratazioko araudiaren menpe), eta hitzarmenak irabazi-asmorik gabeko erakundeekin. Kasu guztietan, zerbitzu eta zentroen baimentze eta homologazioa eta baita lehenengo harrerako prestazioak ere (bereziki balorazioa, diagnostikoa eta orientazioa) kudeaketa publiko zuzenekoak izatera behartzen du legeak, gainerako aspektuetan ekimen pribatuak garaturiko baliabide eta gaitasunak profitatzea hobesten duen neurri berean.

Zuzeneko kudeaketa ez den kasu guztietan, izan itun bidezko modalitatean ala izan zeharkako kudeaketako kontratazio modalitatean ${ }^{3}$, legeak diskriminazio positiboko neurriak ezartzen ditu:

[...] administrazio publikoek lehentasuna emango diete, eraginkortasuneko, kalitateko eta kostuko baldintza antzekoak daudenean, irabazizko izaerarik ez duten gizarte-zerbitzuak eskaintzen diharduten erakundeei.

Eta bigarren puntu bezala gehitzen da:

[...] erakundearen forma juridikoa alde batera utzita, diskriminazio positiboko neurriak aplikatuko dira, besteak beste, hain ibilbidean, honako neurri hauek benetan aplikatu dituzten erakundeentzat: i) Jardueraren emaitza ekonomikoak [...] zerbitzu eta zentroen etengabeko hobekuntzara bideratu izana; ii) Gizarte-egoera bereziki ahuleko pertsona, familia eta/edo taldeei zuzendutako zerbitzuak eskaintzea edo zentroak kudeatzea; iii) [...] zerbitzuari edo zentroari balioa eranstea, zerbitzuaren hartzaile diren pertsona, familia eta/edo taldeei zuzendutako beste prestazio, zerbitzu edo jarduera batzuekin lortzeko; iv) [...] pertsonal kontratatuaren ratio ezarriak hobetzea; v) Erasandako pertsonen parte-hartzea eta gizarte-boluntariotzako jarduerak aurreikustea, elkarlaguntzako jardueren bidez, zerbitzuaren edo zentroaren hartzaile diren pertsona, familia eta/ edo beharrizanak artatzeko, etab. (EHAA $246 \mathrm{zk}$, 65. artikulua: 31902).

Legeak hortaz, hirugarren sektoreko eragileak lehenesteaz gain, horiei egokitu izan zaizkien praktiketara gerturatzen diren gainerako enpresei ere zabaltzen die diskriminazio positiboko neurrien onuradun izateko aukera.

Halaber, Gizarte Zerbitzuen Euskal Sistemako erantzukizun publikoko zenbait zerbitzu eta prestazio hitzarmen eta lankidetza akordio bidez eskaintzea

${ }^{3}$ Kontratazio atalean diskriminazio positiboko neurriez gain gizarte-klausulen ezarpena erregulatzen da: "Administrazio Publikoek, Gizarte Zerbitzuen Euskal Sistemaren Prestazio eta Zerbitzuen Katalogoko zerbitzuak kudeatzeko kontratuak esleitzeko prozeduretan, gizarte-klausula batzuk erantsi dituzte. Besteak beste, honi egingo diote erreferentzia klausulok: erakundearen aldetik arreta jarraituko eskakizuna betetzeari, zerbitzuaren izatasunaren arabera zehazten den denboran zehar, antzeko beharrizanak dituzten pertsona, familia eta/edo taldeei, hau da, zerbitzuaren edo zentroaren hartzaile direnen antzeko beharrizanak dituztenei arreta jarraitua, zerbitzu edo zentro horien kudeaketa esleitu nahi bada, eta bereziki aintzat hartuko da zerbitzua eman behar duen eremuan aldez aurretik egon bada" (72 art.). 


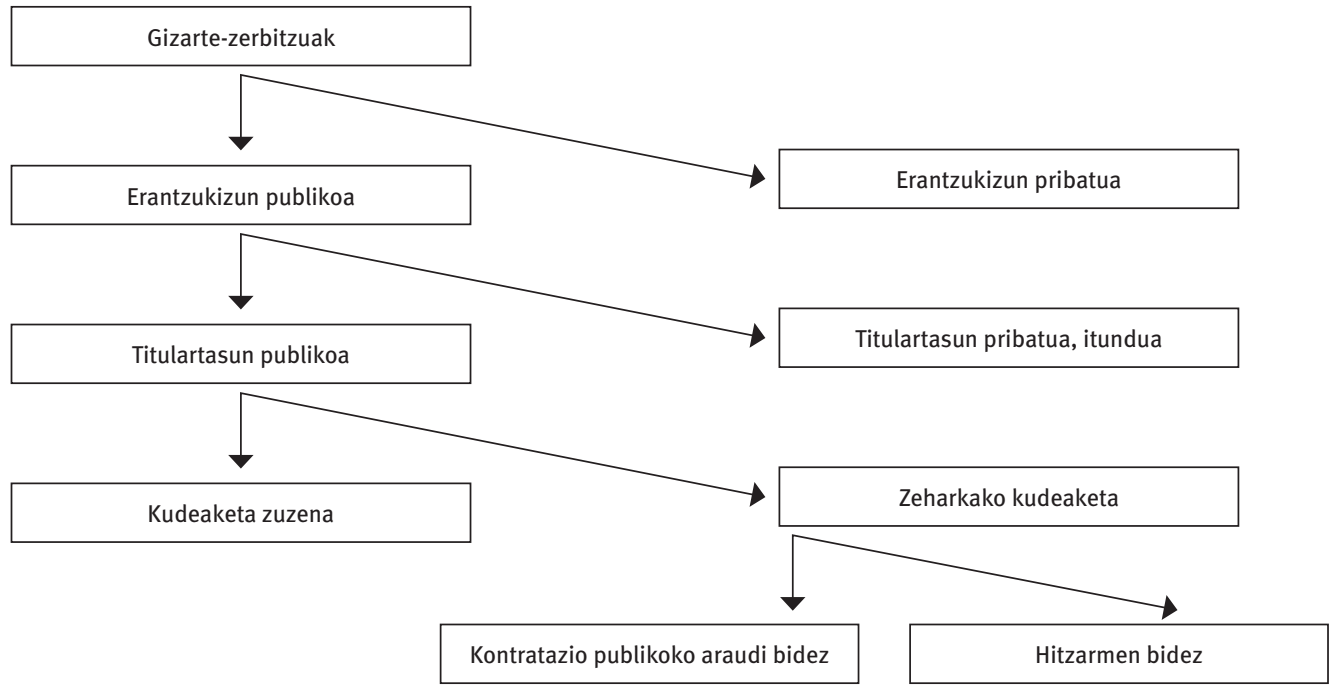

Iturria: Fantova, 2009: 90 (itzulpena egileen lana).

onartzen du, (beti ere zerbitzuaren ezaugarriek horiek ituntzea ezinezko egiten duenean), eta horiek soilik irabazi-asmorik gabeko erakundeekin sinatzera behartzen (69, 70. artikulua). Azkenik, Gizarte Zerbitzuen Euskal Sistemako Katalogoan sartuta ez dauden beste prestazio eta zerbitzu batzuk sustatzeko legeak diru-laguntzak emateko prozedura ezartzen $\mathrm{du}$, beti ere irabazi-asmorik gabeko gizarte-ekimeneko erakundeentzat gordez diru-laguntza horien onuradun izateko aukera (73. artikulua).

Nahasmen puntu bat sortu liteke legeak finkatzen dituen kudeaketa eredu ezberdinen artean, adibidez erantzukizun, titulartasun eta kudeaketa publikoko nozioen artean. Fantova-k (2009) horiek ez parekatzearen beharraz ohartarazten du: titulartasunak ez du zerbitzuaren kudeaketarekin edo azpiegituren jabegoarekin zerikusirik, jarduera bat aurrera eramateko eskubidea eta betebeharra da adierazten duena. Hortaz, gizarte-zerbitzuen egituratze publikoaren eskema jarraian agertzen den moduan sailkatu liteke:

3. Irudian azalduriko eskema garatuz gero, Euskadiko 12/2008 Gizarte Zerbitzuen legean:

- Erantzukizun publikoko zerbitzutzat jotzen dira bai titulartasun publikoko zerbitzuak eta baita administrazio publikoek itundutako titulartasun pribatuko zerbitzuak ere.

- Titulartasun publikoko zerbitzuak izan litezke herri-erakundeek zuzeneko kudeaketaren bitartez hornituak, edo baita zeharkako moduan ere, ekimen pribatuaren (izaera sozial zein merkantilekoa) parte hartzea bideratuz, bai administrazio publikoen kontratazio araubidearen bidez eta baita irabazi asmorik gabeko erakundeekin eginiko hitzarmenen bidez ere.

Legearen izpirituari eutsiz, zerbitzu publikoen esparruan argudio eta arrazoi ezberdinengatik lehenetsi egiten da kudeaketa publikoa (zuzenekoa) edo gizarte-ekimeneko erakundeen kudeaketa (ahal denetan itun bidezkoa). Hala ere, zenbait prestazio, beren ezaugarriengatik, beti kudeaketa publikokoak izatea ezartzen du legeak, baita gizarte-ekimenetik ordura arte garaturiko gaitasunak probestea ere.

Zerbitzu publikoen hornikuntzan ekimen pribatuaren esku hartzea arautzeko modu nagusi gisa itun-erregimen espezifiko bat ezartzea aurreikusten du legeak (zeina ez den nahastu behar kontratazio araubidearen baitan kontenplatzen den ituntze modalitatearekin). Itun-erregimenerako zein zeharkako kudeaketarako diskriminazio positiboko neurriak ezartzen dira, zeinaren bidez baloratu, aintzatetsi eta sustatu nahi diren arestian aipaturiko gizarte-balio erantsiak.

Fantova-ren iritziz (2009) gizarte-zerbitzuen ibilbideagatik eta egungo abagune historikoak eraginda, 12/2008 legeak zuzeneko kudeaketa publikoak bazterreko tokia izango duen agertoki batetara garamatza, ikuspuntu kuantitatibo batetik begiratuta batik bat. Hargatik ondorioztatzen du zuzeneko kudeaketa publikoa kualitatiboki erabakigarriak diren alorretan zentratu behar dela nagusiki, estrategikoki esanguratsuak diren esparruetan, alegia. Bere ustez legeak ezartzen ditu Gizarte Zerbitzuen Euskal Sisteman ekimen pribatuaren eskuetara delega ezinak diren jarduera eta egiturak, baina horrez gain, aipatzen du ez dela bilatu behar jadanik ekimen pribatuak eskaintzen duen zerbitzu baten eskaintza publiko 
paralelorik ezartzea. Kudeaketa publiko zuzeneko masa kritiko nahikoa mantendu beharra aldarrikatzen du halaber erreferentziazko zuzeneko arretaren esparruetan, besteak beste, ezagutzaren kudeaketa esparruetan (ikerkuntza, berrikuntza etab.), eta baita kudeaketa prozesu nagusietan ere (planifikazioa, ebaluazioa, irudiaren kudeaketa, harremanen kudeaketa, etab.) ekimen pribatuaren aurrean posizio berrindartu batekin agertzeko.

Azkenik, hirugarren sektoreari edo gizarteekimeneko erakundeen inguruan ñabardura garrantzitsu bat gehitzen du. Nabaria da 12/2008 legea bere artikulatu osoan gizarte-ekimeneko erakundeak aitortu, babestu eta sustatzearen aldeko erreferentziez beteta dagoela. Honek bete betean bat egiten du gizarte-zerbitzuei eman nahi zaien eredu komunitarioarekin, pertsona erabiltzailea ahalik eta denbora gehienean bere gertueneko espazioan eta gizarteharremanen esparruan mantendu nahi izatearen helburuarekin, alegia.

Hala ere ñabardura interesgarria egiten du hirugarren sektoreari atxiki izan zaizkion forma juridikoen erabilpenaren inguruan. Egilearen irudiko forma juridikoak geroz eta esangura ahulagoa du kontu guzti honetan, ez baitu inola ere bermatzen berez egotzi behar litzaizkioken gizarte-balioak egiazki eskainiko dituenik. Hori hala da bi prozesu elkarloturen ondorioz: alde batetik gizarte-ekimeneko forma juridikoen erabilpen instrumental eta okerra egiten ari delako errealitate horrekin zerikusirik ez duen eragile zenbaiten aldetik, eta bestalde, gizarte-ekimeneko erakunde asko eta asko progresiboki elkartasunezko erakundeenak ez diren logikez kolonizatuak izaten ari direlako (Fantova, 2009:94). Hargatik bilatu nahi izan da legean forma juridiko konkretu batzuk faboratu beharrean praktika konkretu batzuk (normalki gizarteekimeneko erakundeen praktikei lotu izan zaizkienak) lehenestea, izan forma juridiko bat ala beste.

\section{Adituen panela: gizarte-zerbitzuen izaera mistoa eztabaidagai}

Jarraian garatzen dugun kapituluan hiru galdera nagusiri buruzko eztabaida berregingo dugu. Hiru galdera nagusi horiek orain arte teorian landuriko eztabaidak mahai gaineratzea dute helburu. Lehenik, teorian ezarririko ongizate-erregimen eredu ezberdinetatik, Euskadiko gizarte-zerbitzuena zein eredutan kokatua legokeen jakin nahi izan dugu, horrek ezarriko baitu gure abiapuntuko posizioa, etorkizunera planteatu nahi den eraikinaren lurzorua, hain zuzen ere. Bigarrenik, aipaturiko legeen bitartez gizartezerbitzuen izaera mistoa zein modutan definitzen den aztertu nahi izan dugu, definizio horrek sistemaren kudeaketaren gain sortzen dituen arazoei bereziki erreparatuz. Azkenik, lege horietan zeharkako kudeaketaren izaera komunitarioa bermatzeko aplikaturiko mekanismoak aztertuko dira, horien justifikazio eta aplikazio arazoak aztertuz.
Iritzien aniztasuna bermatze aldera, gizartezerbitzuen sektorean diharduten jatorri ezberdineko berri emaileekin osaturiko lagina burutu dugu: herri-erakundeetako goi karguetan diharduten politikari eta teknikariak alde batetik, (5 guztira) kooperatiba, fundazio eta elkarteetako arduradun diren adituak beste aldetik ( 7 guztira), eta bestelako gizarte-eragileak azkenik, gizarte-zerbitzuen ikerketan espezializaturiko bi aditu, esparru sindikaleko ordezkari bat eta mugimendu feministako kide bat (ikus Eranskina).

Kontuan izan behar da erantzunak interpretatzerako orduan gure ikerketan parte hartu duten aditu gehienek Gipuzkoako lurraldean jarduten dutela, gure ikergaia konkretuki Gipuzkoako pertsona nagusiei bideratutako gizarte-zerbitzuetan oinarritu baita ${ }^{4}$. Hortaz, jaso ditugun erantzun batzuk testuinguru horretara soilik dira aplikagarriak, nekez orokortu daitezke gainerako herrialde eta gizarte-zerbitzuetako azpi-sektoreetara, gauza jakina baita gizarte-zerbitzuen sistema ezberdinak ditugula Euskadin herrialde batean eta bestean. Azken urteetan konbergentzia prozesuak abian jarri badira ere, oraindik orain hiru eredu diferentziatu ditugula defendatzen dute azterketa berrienek (SIIS, 2012). Dena den, eztabaidak ahalik eta modu orokorrenean planteatzen saiatu garenez gero, uste dugu jasotako eztabaida batzuk nahiko modu leialean jasotzen dituztela Euskadi mailan oro har, gizarte-zerbitzuen kudeaketa ereduen inguruan dauden posizionamendu ideologiko ezberdinak.

\subsection{Non gaude? Euskadiko ongizate-erregimenaren analisia}

Europako erregimenak erreferentziatzat hartuz, adituen iritzian gure kokapena modu honetan definituko litzateke:

[...] gure lekua [...] geografikoki nahiko gurutze zea danez, ba geografikoki hor erdi, e, bidegurutze batean gaude, eta maila honetan ere bidegurutze batean gaude. Orduan ba gu nordikotatik pixka bat hartzen hasi gea, e, unibertsaltasuna, e, eskubide subjektiboak, ez? hortik ere hasten ari gara edukitzen ezaugarri batzuk. [...] Estatu mailatik datorkigun araudi guztia, e, desenpleguko eta pentsiokoa batez ere ba oso korporatista da, hori ere egia da. Egia da hemen apustu bat egin dala eta hori da nordikoen apustu bat estatuaren interbentzioaren aldeko apustu bat egin dala. [...] Igual urrutiena agian egia da modelo liberala, nik uste dut baietz, bueno modelo liberaletik eukiko genuke selektibitate pixka bat, baina ez gehiegi, [...] baina bueno nik uste det modelo hori ez dala gure tradizioan egon eta gero bilakaera politikoa ez doala horruntz, ez? [...] nordikoetaruntz joan

4 Artikulu hau 2012. urteko Urrian EHU-n aurkezturiko gure Doktorego Tesian oinarritzen da, "Gizarte Ekonomiaren aukera zaintzen krisiaren aurrean: Gipuzkoako pertsona nagusien alorra aztergai” izenburupean aurkeztu zuen lan hau Enekoitz Etxezarretak EHUko Ekonomia Aplikatua I sailetik, zuzendaritza lanetan Baleren Bakaikoa eta Mikel Zurbano irakasleak izan zituelarik. 
gara maila batean, nik ustet, mediterraneotatik ez gea guztiz aldendu, eta askotan gure leku naturala izango litzateke ba hori zentroeuropearra, Alemania, Frantzia (C.2).

Pertsona honen irudiko beraz, bidegurutze batean geundeke: kulturalki eta soziologikoki mediterranearrak gara oraindik, batik bat familiak duen garrantziagatik baina baita presio fiskal apalago bategatik ere, besteak beste; instituzionalki eredu korporatistako elementu asko dauzkagu, hirugarren sektore indartsu bat edo gizarte-segurantzako sistema kontributiboa, esaterako; baina apustua, etorkizuneko apustua, herrialde nordikoetako erreferentzia sozialdemokratan dago, eskubideen unibertsaltasuna eta estatuaren esku hartze handiagoa ipar harturik.

Beste aditu honen arabera, gure erregimenak ezaugarri propioak izanagatik ere, erregimen ezberdinetako elementuen nahasketa bat agertuko da, eta hiru elementuk egingo dute bereizgarri: sektore publikoaren hedapen berantiarrak, familiaren parte hartze handiak eta hirugarren sektorearen pisu esanguratsuak:

Yo sí que creo que hay, o veo más claramente, la diferencia de cuatro regímenes y, ciertamente, pues en ese sentido, el caso español forma parte de un modelo de Estado de bienestar tardío, donde el papel de la familia, pues es mucho más preponderante que en otros, ¿no? [...] hombre, pues yo diría que, dentro de lo que puede ser el ámbito español, pues no cabe duda de que el País Vasco [...] constituye un modelo más avanzado, más desarrollado de Estado de bienestar y especialmente en el ámbito de los servicios sociales, y que, en ese sentido, pues sí es verdad que las características sociológicas o culturales del País Vasco, pues han dado también un protagonismo del tercer sector en algunos servicios (A.1).

Hiru izanik ardatz nagusiak, hots, estatua, familia eta esparru pribatu/komunitarioa, ez dago hain argi hiru horien arteko oreka zein modutakoa den, hiru horien zein aldetara tolesten den balantza:

[...] yo en este momento, si tuviera que decantarme por los tres modelos que decías, el público, el privado o el informal, yo diría que está, por el peso de las prestaciones, claramente decantándose por el público, porque es verdad que, en gran parte de las familias que atienden a personas dependientes, las atienden en casa, pero también es verdad que reciben una prestación económica y muchas de ellas además, porque son compatibles, reciben servicios de ayuda a domicilio, o incluso van al centro de día. Con lo cual, ¿público? Pues yo creo que sí, a través de las prestaciones, sin duda alguna (A.3).

Es mixto. [...] Es decir no hay un claro vencedor entre los tres sectores [estatua, merkatua, familia], yo creo que los datos sí apuntan a eso. [...] Es verdad que tenemos unos agentes del mercado bastante potentes en Gipuzkoa, pero claro, bajo responsabilidad pública. Es decir, no compiten con la administración pública, sino [que] están bajo responsabilidad pública, contratan para la Administración. Tienes un tercer sector sin ánimo de lucro con una relevancia muy importante en Gipuzkoa, sobre todo en el campo de la discapacidad, [...] y sí que hemos visto en los últimos años un incremento de las tres [...], sea por reconocimiento a través de la Ley de la Dependencia, bien sea porque la administración pública ha ido creando más servicios, bien sea porque la iniciativa privada también ha crecido al albur de las decisiones que ha tomado la Administración de incremento del gasto social (A2).

Orain arte aipaturiko diagnostikoetatik, honako aldagaiak nabarmenduko lirateke, beraz: lehenik esparru informalak izaten jarraitzen duen garrantzia eta bigarrenik hedadura publiko garrantzitsu bat, nagusiki, prestazioen bidez esparru informal hori diruz laguntzera bideratu dena, baina baita zerbitzu berrien kontsolidazio bidez ekimen pribatuaren parte hartzea erakartzen joan dena. Familia eta estatuaz aparte beraz, irudi luke esparru pribatuak oro har, nahiko garrantzia apala leukakeela konfigurazio instituzional honetan:

En este momento, privado, sin la subvención o sin las plazas concertadas con la Administración, podemos contar con los dedos de una mano, pero con un dedo igual y nos sobra, ¿eh? (A.3).

Lehen galde sorta honen ondorio gisa aipatuko genuke aditu gehienen iritzian adostasun nahiko zabala dagoela gutxienik bi puntutan: i) esparru pribatuaren garrantzia erlatiboki ahula, beti ere herri-erakundeen kontrolpean dihardutelarik, eta; ii) sektore publikoaren garrantzia erlatiboki handia, batik bat konparaketa Espainiako bestelako autonomia-erkidegoekin eginez gero. Datu objektiboak aztertuz gero, begien bistakoa da oraindik orain familia esparrua dela kuantitatiboki zerbitzurik gehien eskaintzen dituen gizarte-egitura5 ${ }^{5}$ baina bertoko adituen pertzepzioari eutsiz, badirudi Euskadiko egoerak badituela elementu bereizgarriak, nagusiki sektore publiko indartsuago bat eta hirugarren sektore errotu bati lotuak. Sistema misto gisa hauteman behar litzateke, hortaz. Ikustagun, baina, sistema hori nola definitzen den eta zein koordinazio arazo agertzen dituen.

${ }^{5}$ Espainia mailako daturik berrienetatik abiatuz, Imserso-k gaiari buruz argitaraturiko azken txostenaren arabera (Rogero, 2010), datuak honakoak lirateke: laguntza pertsonalak jasotzen dituzten pertsona nagusien \%89ak zaintza informala jasotzen du, eta horien artean \%77,5arentzat zaintza informala da jasotzen duen laguntza bakarra. Euskadiren errealitatea aztertzen duten dokumentuetara joz gero, berriki Eusko Jaurlaritzak Ingema-ren laguntzaz argitaraturiko Pertsona Nagusien Bizi Baldintzen Inkestan (ECVPM- Euskadi 2010) ere esparru familiarrean emaniko zaintzen nagusitasuna azaleratzen da, nahiz eta estatu mailako datuek baina portzentaje apalagoak eman. Honela, 60 urtetik gorako pertsona ez instituzionalizatuek jasotako laguntza guztien $\% 52$ familiarren aldetik jasotzen dute soilik eta \%72ak familiarra gehi bestelako laguntza formalen konbinazioa da hautatzen dutena. 


\subsection{Eredu mistoaren definizioa eta kudeaketa arazoak}

Aipatu bezala, gizarte-egitura ezberdinek parte hartzen duten neurrian esan genezake Euskadiko gizarte-zerbitzuenak eredu misto bati jarraitzen diola. Euskadiko 12/2008 legean ere oso modu agerikoan defendatzen da eragile ezberdinen parte hartzearen beharrezkotasuna. Hala ere, legeak ezartzen du nolabaiteko funtzio banaketa bat, eragile bakoitzak bere erantzukizunekotzat eta delega ezinekotzat jo beharreko esparruak zehazten ditu. Funtzio banaketa honek esan genezake definitzen duela eredu misto honen izaera eta osaera, modu honetan finkatzen dena:

La Ley [gizarte-zerbitzuena] lo que habla es de un sistema de responsabilidad pública y provisión mixta. Eso supone que la Administración financia, controla, regula, evalúa, pero no necesariamente asume todos los aspectos que tienen que ver con la gestión, la coordinación de casos y muchos más (C.1).

Funtzioen banaketa hori nahiko definitua dago legez, eta nahiko partekatua gainera sektorean diharduten eragileen aldetik:

Esto deviene prácticamente de la Ley de Servicios Sociales, que al final consolida un modelo que ya existía. Entonces, de administración pública son: provisión de servicios, reglamentación, planificación, financiación, valoración, inspección y control. Esos son teóricamente indelegables. ¿Entidades de iniciativa privada?: prestación de servicios reglamentados por la Administración, apoyo a procesos de valoración -insisto apoyo, no la valoración en sí-, cobro de la aportación económica del usuario, trabajos de asesoría y construcción y mantenimiento de infraestructuras. Así queda consagrada (A.2).

[...] cada vez está más claro que la responsabilidad de la calidad y de la provisión de los servicios es de la Administración, y yo creo que esto lo tienen muy claro, y por tanto,[es] garante de la atención, eso sí, mayoritariamente prestada por empresas privadas. Entonces, la Administración tendría que garantizar, a través de los recursos necesarios, la calidad prestada a través de todas estas empresas de servicios (B.3).

[...] y luego, como digo, el hecho de que el desarrollo también de las políticas públicas haya llevado a unas conclusiones, ¿no?, es decir, bueno: 'zapatero, a tus zapatos', es decir, ¿en qué es bueno el sector público? Pues bueno, en regular etcétera, etcétera, pero en la propia prestación del servicios, ¿necesariamente es mejor? Pues quizás no, ¿no? Y entonces, ahí es donde aparecen las sinergias que tiene una iniciativa social, un tercer sector, desde el momento en el cual, pues bueno, puede generar unos mecanismos de participación, de autorresponsabilización, de colaboración que son interesantes para la propia prestación de este servicio (A.1).
Legeak era berean, erakunde pribatuen parte hartzea hornitzaile funtziora mugatzearekin batera, hornikuntza honetan, arestian ikusi dugun bezala, paper berezia egokitzen die hirugarren sektoreko eragileei.

[...] el reconocimiento de ese modelo mixto con especial papel para el tercer sector en nuestro entorno tiene varias explicaciones. Una explicación es precisamente el desarrollo tardío del Estado de bienestar. [...] Y el hecho de que cuando se empieza a organizar, cuando se empieza a desarrollar, ya había una iniciativa social al menos en algunos ámbitos, bien por [parte de] asociaciones de familiares, bien por [parte de] la Iglesia o por [parte de] otro tipo de agentes, pues bueno, ha hecho que, en el ámbito de los servicios sociales, este tercer sector gozara de una legitimidad, a la hora de no ser sustituido, sino de ser apoyado, ¿no? Entonces, si le sumas desarrollo tardío con un poco las amenazas de la sostenibilidad que se visualizan en sectores como el sanitario, ¿no?, donde la combinación de gestión pública directa con ausencia de copago, pues genera, en una sociedad consumista como la nuestra donde realmente pues, eh..., no nos caracterizamos por la contención en aquello que se nos da de forma gratuita, posiblemente, pues, bueno, genera ahí una serie de contextos en los cuales, pues parece que no hay un cuestionamiento, ¿no?, y de hecho, pues la Ley de Servicios Sociales de 2008 en el País Vasco, pues consagra de alguna forma ese modelo mixto, ¿no? (A.1).

[...] bueno osasunien izan da ez? Guztiz publikoa ta ikusi da behintzat ikusi dien datuak zeintzuk dien eta nondik joango dan, orduan nik usteot zerbitzu sozialek ez dabiela eingo osasunean ein dan bide berdina. Bai, nik usteot eredu mistora fango garala [...]. Eta hor sartuko dala ba ez dala ia bakarrik administraziño publikoaren gauza bat, bai ekonomikoki eta bai erantzukizun aldetik, beste agente batzuk be hartu beharko dabiela eta familiak be, ba kopagoarena adibidez be, ba asko esaten da (B.6).

Alde batetik, beraz, hirugarren sektore indartsu baten aurretiazko existentzia, eta beste aldetik, zerbitzu publikoen iraunkortasunaren inguruko zalantzak, bi horiek dira eztabaida hau gidatzen duten giltzarri nagusiak. Beste era batera formulaturik, sistema mistoaren atzean gordetzen diren bi justifikazio nagusiak, bata, ekimen pribatuarekin egin beharreko banaketa funtzional baten argudioa litzateke, eta bigarrena, ereduaren kostua, hornidura publikoko ereduaren iraunkortasunaren gaineko zalantzak eragiten dituena.

Lehen aferari dagokionean, hirugarren sektorea sektore publikoaren aurretik jardun izanak, zenbait abantaila eman dakizkioke zerbitzuan beharrezkoak diren ezagutza eta kualifikazio mailari dagokionez. Zentzu horretan, eredu mistoaren justifikazioa, zentzuzko banaketa funtzional batean oinarritzen da, hots, 'bakoitza ondoen egiten dakien horretan' espezializatzearen aldeko argudioetan. 
Banaketa funtzional honek, ordea, arazo bat baino gehiago sortzen ditu sektore publikoarengan, alde batetik ezagutzarekin zerikusia dutenak, baina baita kudeaketarekin loturikoak ere, zeharkako kudeaketaren bitartez sektore publikoaren irismena eta kontrolerako gaitasuna mugatzen baita, kontuan izanik bera dela, azken buruan, emaniko zerbitzuen finantzatzaile eta erantzule nagusia.

Aber, hemen ez da ondoen egitearen kontua. Ondoen egin behar duzu egitea tokatzen zaizuna! Neri hor definizio hori iruitzen zait oso hirugarren sektorekoa, esan nahi dizut, guk ondo eiten dugu zerbitzua eta administrazioak ez du ondo egiten zerbitzua. Hori hirugarren sektoreak esatea, barkatuko diate baino, nik daukat ardura osoa, sentitzen det. Eta nik kontratatzen baldin badet ardura delegatu egiten det baino delegatu bakarrik, ardura nerea da! [...] Guk dauzkagun ekipoekin eta udaletan bereziki, [...] ezinezkoa da esparru guztietan dagoen jakintza maila, eredu berrien gainean egotea informatuta, ezinezkoa da, ez dauzkazu ekipo teknikoak horretarako hainbestekoak, [...] eta beraz egia da, niretzat hori da daukagun problema, hau da, kanpokoen eskutan utzi behar dugula ezagutzaren espezializazio horren kontua [...]. Baino, hori da kontua, uzten baldin badezu... Osea, esaten baldin bada 'ondoen egiten dutena' hoixe ondoen egiten dutela! eta gainea ondoen egiten dutelako, jarraituko dute ondoen egiten beaiek eta zu gero eta jibarizatuagoa geldituko zea administrazio bezela, ez dezu ezer jakingo horri buruz! Etzea gai izango definitzeko ez beharrak, ez ezerre! ez ze zerbitzu maila, beraz horrekin ezin dezu oso urrutira jun (A.5).

[...] porque aquí sí que hemos visto un problema muy importante [...] Hay empresas que tienden al monopolio, a crecer mucho y a ocupar gran parte de su servicio. Claro, cuando tienen problemas, te amenazan con arrastrarte con ellos. [...] Y eso es un grave problema. $Y$ te resta margen de maniobra, ¿eh? Ése es el problema. [...] Y en el régimen de contratación, todavía, pero es que en los regímenes que tenemos establecidos aquí en varios servicios, a cincuenta años, o sea, es atar a la Administración a una empresa determinada durante cincuenta años. Claro, los problemas son cada dos por tres. ¿Qué pasa si no tienes solvencia de repente? (A.2).

Cuando, por ejemplo, yo [herri-erakundeak] calculo que el absentismo tiene que ser del $8 \%$, y tú calculas que vas a financiar el $8 \%$. Por lo que sea, en esa residencia, pues es del $20 \%$, por poner un ejemplo, ¿eh?, o del $15 \%$. ¿Es normal que sea el $15 \%$ ? ¿Tú, como responsable del centro, no podrías, entre comillas, gestionar un poquito esas bajas, a ver a qué se deben, e intentar bajar igual? [...], porque si no, ahí tienes una fuga de gastos (A.3).

[...] y te [enpresa hornitzaileak] dice, "a propósito, la semana pasada tuve que firmar el convenio colectivo y bueno firmé el IPC más 0,5, porque así aseguramos la paz social, y tal...”. Y dices [herrierakundeak]: “¿pero que me dices a mí?, o sea ¿tú no eres la patronal? 'Tú sabrás lo que tienes que negociar, pero no me vengas después aquí diciendo que te pague el IPC más 0,5, ¿eh?” (A.4).

Zeharkako kudeaketak beraz, arazoak sor ditzake batik bat botere harremanak, bai kudeaketa ahalmenari baina baita ezagutzaren jabetzari loturikoak ere, sektore publikotik at desplazatzen dituelako, eta hortaz, sektore publikoaren erregulaziopean diharduten erakundeak izan arren, azkenean sektore publikoak hartu behar dituelako beregain berak erabakitzerik izan gabe finantzaketa eta zerbitzuaren kalitatean eragiten duten hainbat afera.

Hala ere, eta zeharkako kudeaketak aipaturiko arazo hauek sortuagatik ere, asko dira zuzeneko kudeaketa publikoari etorkizunik ikusten ez diotenak, arrazoi ezberdinak tarteko, baina nagusiki lan kostu garestiagoen errealitateak eraginda:

Bai, bai, alde batetik da garestiago eta beste aldetik oso lotura handixa dauka ba zenbait gauzatarako [...] administraziñoko zentro nola den, aplikatuko lituzkete administraziñoan dauken baldintzak eta klaro administraziñoko baldintzak eztia hortarako kalkulatu. [...] Horregatikan hori pikutara dijoa. Hori desagertzera doa (B.4).

Gero beste gauza bat dago, eta da, e, zerbitzu hoien kostea. Gipuzkoan ez dela hainbesteko problema baina adibidez Araban oso problema handia da, eta gertatu daiteke izatea. Eta hor hitz egin behar da hor daudela pribilegio batzuk, e, jasanezinak direnak. Jasanezinak direnak. Langile publiko batek kobratzen duen dirua eta dituen eskubideak eta exijitzen zaion askotan lan konpromisoa, ez det esan nahi denak daudenik hor kafea hartzen egunero, baina ez da, e..., ez dakit nola esan sostenigarria, e..., hemen lanean ari dan langilego guztia langile publikoak dituzten lan baldintzak eukitzea. Goitikan ezin da parekatu incluso presio fiskala danesa izanda ere... (C.2).

Yo creo que hay una realidad clara y es que los costes derivados de la gestión pública de los centros, pues son costes muy elevados, y en algunas ocasiones difícilmente controlables, y en ese sentido, hay que ser claros. La prestación de servicios a través de empresas privadas, pues está mucho más controlada (B.3).

Ikusten denez beraz, sektore publikoaren iraunkortasuna zalantzan jartzea, batik bat, sektore honetako kostuei, eta zehatzago esanik, lan-kostuei loturik agertzen da, eredu publikoa eredu mistoa baino askoz garestiagoa dela uste baitute batzuk. Beste zenbaitek, ordea, ezeztatu egingo dute argudio hori:

Está condenada a desaparecer [kudeaketa publikoa] por una decisión política [...]. Creemos que a la larga el modelo de subcontratación es 
bastante más caro, en función del precio-coste y servicios dados que los servicios que tenemos actualmente, ¿no? El gran problema no está ahí. Nosotros creemos que, en este país, si toda la discusión o el debate se genera en torno a cómo hay que gastar lo que hay, evidentemente no hay posibilidad de meter tu cuña. Porque no nos dejan discutir lo previo, ¿no? ¿Qué se ingresa? (C.3).

Claro, la iniciativa privada no es imprescindible [...]. Y tampoco es inevitable. Eso hay que dejarlo sentado. ¿Cuál es el principal problema? Más allá de la introducción del ánimo de lucro en la prestación de servicios, que es algo que debería motivarnos una reflexión, ese teórico abaratamiento de los servicios, que no es tal [...]. El modelo que se importó hace veinte años de Gran Bretaña de iniciativa de financiación privada (Private Finance Initiative), ese modelo no es más barato. Es decir, se ha demostrado que, a los años, sale más caro a la Administración (A.2).

Azken bi elkarrizketatu horien iritzian hortaz, ez da hain agerikoa eredu azpikontratatua merkeagoa denik, ereduen kontratazioan mozkin asmodun enpresak sartzeak merezi luke bestelako gogoetarik eta gastuen inguruko eztabaida soilik planteatzea ez da zuzena sarreren, hau da, zerga-politikaren inguruko eztabaidarekin loturik ez badoa, bederen.

Edozein delarik ere norberak eztabaida honetan defendatuko lukeen eredua, egiazki ez da guztiz muturreko eredurik planteatzen ari, ez hertsiki publikoa izango denik ez hertsiki pribatua izango denik ere, ezta hertsiki familiarista izango denik ere, eredu mistoak ez baitu esan nahi sektore publikoa guztiz desagertzera doanik, ez eta sistema osorik familiarengan oinarrituko denik, baizik eta oreka bat egon behar duela gizarte-egitura guztien artean:

El sistema de Servicios Sociales descansa sobre un equilibrio entre el cuidado formal y el cuidado informal, y ese equilibrio hay que preservarlo. Tiene que ser absolutamente compatible con la incorporación de las mujeres al trabajo fuera de casa, hay que trabajar también por que los hombres asumamos más responsabilidades que tiene que ver más con el cuidado informal, pero hay que tratar de preservar lo más posible ese equilibrio. Por detrás de esto hay opciones ideológicas, y todas son legítimas, que tienen que ver con el modelo de sociedad, y nosotros creemos que debe seguir habiendo participación de la sociedad civil en la respuesta de las necesidades sociales y en materia de servicios sociales, que la familia tiene que seguir teniendo un papel y que hay que seguir buscando el equilibrio (C.1).

Bueno nik uste det modelo mistoa ondo dagola, baina modelo mistoak ez du esan nahi modelo publikoa desagertu behar denik. Modelo mistoak esan nahi du egon behar direla plazak publikoak, gestio publikoarekin, eta egon behar direla beste plaza pribatuak gestio pribatuakin, hori da modelo mistoa. Osea modelo mistoa ez da bakarrik batzuk egin inspekzioa eta abar eta besteak prestazioa (C.2).

Bai, bai, nik uste baietz, batez ere nik uste dut, osea, eske ez dakit nola esan, eske lan asko dago! Lan asko dago eta diru asko behar da. Hori hasteko, orduan ba bueno, ez dakit, pentsatu behar duzu ez duzula lortuko zerbitzu publikoekin bakarrik, familiarekin argi dago ezetz, ez dozula lortzen, e? Ze gainera eske jendea ez dago ondo zainduta. Familiarekin bakarrik jendea ez dago oso ondo zainduta [...]. Orduan estatuak bakarrik segurasko ez orduan guztiok hartu behar dugu parte. Baina klaro tranpa egiten digute instituzioek, egite dutena da bai bai guztiok hartu behar dugu parte orduan orain benga komunitarioa eta... ez, ez, zerbitzu publikoak bebai, ulertzen? Orduan izan behar da dena batera, iruitzen zait niri, e? (C.4).

\subsection{Zeharkako kudeaketa komunitarioaren justifikazioa eta diskriminazio arazoak}

Euskadiko gizarte-zerbitzuen sistema sistema misto gisa definitzen da, nagusiki hertsiki sistema publiko gisa egituratzeko ageri dituen zailtasunengatik, baina baita maila ideologiko batean ere, 'guztientzako tokia' duen gizarte-esparru gisa hautematen delako ere. Sistema misto honen kudeaketa arazorik nabarmenenak, ikusi dugunez, zeharkako kudeaketaren puntuak sortzen ditu, honek sektore publikoarengan sortzen dituen albo-kalteen ondorioz.

Aipatu dugun gisan, zeharkako kudeaketa hau bideratzeko, Euskadiko 12/2008 legeak aipamen berezia egiten du hirugarren sektoreko erakundeak, edo horiei egotzitako praktiketara gerturatzen diren erakundeak lehenesteko, zeharkako kudeaketa hau esparru komunitarioari atxiki nahian. Eta horretarako diskriminazio positiboko neurriak ezartzen ditu, ikusi dugun eran, zuzeneko kudeaketa ez den modalitate guztietarako.

Puntu honek, elkarrizketaturiko pertsonen artean mota askotako erantzunak jaso ditu, baina ez da inondik ere adostasun zabalik erdiesten, ez herrierakundeetako arduradun ezberdinen artean, ez hirugarren sektoreko eragileen artean ez eta bestelako gizarte-eragileen artean ere. Herri-erakundeen artean, aldekoak baino zalantzan direnak gehiago dira, hirugarren sektoreko eragileen artean ere, gehiago dira zalantzan direnak aldekoak baino eta beraz, interesgarria da ikustea puntu honek ez duela adostasunik sortzen ez harengandik faboratuak izan litezkeenen artean, ezta hori aplikarazi behar dutenen artean ere.

Azalduriko argudio eta jarreren artean nabarmen alde daudenetatik honako argudioak azaldu dira herrierakundeetako arduradunen aldetik:

Bueno, sí estoy de acuerdo, y la justificación viene por el valor social añadido que aportan las 
entidades del tercer sector, es decir, de alguna manera entidades que se autolimitan en la obtención del lucro, o que incorporan personas con dificultades de empleabilidad o promueven la participación, aportan un valor social añadido que debe ser reconocido por lo poderes públicos y que se traduce en una discriminación positiva que les permita no tener que competir, entre comillas, en pie de igualdad con la empresa con ánimo de lucro (A.1).

Gizarte-balio erantsi bati buruz dihardu, ekonomikoki neur ezin litekeena eta gizartean betetzen dituzten bestelako funtzio sozial batzuekin lotura leukakeena. Beste zenbait eragileren ustez, aldiz, aldeko argudioak jatorri ukigarriagoa du, mozkin asmorik ez izatea da gehien nabarmentzen den ezaugarria, hori eta horrek dakarren guztia, besteak beste, zerbitzuak merkeago eskaini ahal izatea, gardentasuna kudeaketan edo iraunkortasuna lurraldean, modu horretako argudioak azalduko dira mozkin asmorik ez izateari lotuta:

[...] porque el precio/hora que se presenta en el concurso se les demuestra donde se gasta, porque yo presento...yo desgloso una nómina y desgloso todo el precio/hora a dónde se va, y ahí se ve lo que queda para los gastos generales y para los proyectos y para esas cosas. Más transparente que nadie, por las exigencias que tenemos que cumplir (B.1).

Zegatik? Gaur egun eta arlo honetan jokatzen ari dira enpresa pribatuak ikusten dutelako ba badagoela aukera bat dirua etarateko, zergatik sartu behar da Mondragon kooperatiba? Ba ikusten duelako hemen badaukala irabazteko zertxobait. Zer pasatuko luke egunen baten iristen baldin bada ba ez dagoela aukera ba lukroa eukitzeko? Hoiek danak irten ein behar dira. Eta aurretik gaudenok? Eta lukro barekuak ba jarraitu eingo degu zeren eta gure esentzia ez da hori, ez da hori eukitzia baizik eta guria da atenditzia jentia, eta ordun gure kontuak egoten dia ero nibelatuta ero galerarekin, e? Orduan erakutsi egiten degu egoera horretan be bai, gaizki egonda, jarraitu egiten degu lana egiten (B.4).

Justifikatzen duten argudioak, bat da bueno alde batetik igual sinpleena da baina da rentabilidade ekonomikoa, osea, un coste menos que tienen, que es el de buscar dividendos para sus accionistas. Hori lehenengoa da, suposatzen da berez merkeago egingo dutela. E, bigarrena da entidade hauek gehienak hemen zeudela eta hoiek izan direla gauzak mugitzen hasi direnak. Gainea irabaziaren kontua ez da bakarrik diru kontua baizik eta badakigula hauek errotuagoak daudela territorioan, ez? [...] Eta orduan lurraldean errotuta egotea inportantea dala, eta lurraldean errotuta egoteko hirugarren sektorea askozaz ere egokiagoa da. Eta gainera beraiek ondo egin dutela denbora askoan, jendetik askozaz ere gertuago daudela, ez? orduan nik uste det ez dakit ekonomistek esaten duten bezela sinergia asko daudela ez? Eta enpresa pribatuek ez det esaten ezin dituztenik lortu, baina arazo gehiago dazkate lortzeko (C.2).

Azkenik, kooperatiben mundutik gertu dagoen pertsona batek ekarpen interesgarria egiten duela iruditzen zaigu, alde batetik herri-erakundeen aldetik babes neurriak izatearen egokitasuna defendatzen baitu, baina bestalde, bestelako irizpide batzuk gehitu beharra aipatzen du babestu beharreko eragileen definizioa egiteko, eta mozkin asmorik gabeko izaeraren birdefinizio bat proposatzen:

$\mathrm{Ni}$ ados eongo nintzake. Baina karo arazua da nola baieztatzen dozu, nola frogatzen dozun benetan diskriminaziño positibo hori eitxen dotzazun enpresa edo entidade hori benetan irabazi asmorik gabekoa dan. Ta gero ez da bakarrik sin ánimo de lucro hori eukitzea atzian, ba lehen esan doguna, ez?, kooperatiba bat, hor desberdintasun hori eitxia garbi dago osea, kooperatiba bat izan leike con ánimo de lucro baina ez bere sozioak irabazten urteteko baizik bueno ba rebertitzeko beren negozio horretan, lanpostu gehiago sortzeko, osea, beste ikuspegi sozial batekin eta hori da sin ánimo de lucro be bai (B.6).

Oso argi mintzo da, zentzu honetan, gizartezerbitzuen legearen diseinuan parte hartze eta garrantzia esanguratsua izan zuen pertsonetako bat, argi uzten baitu legeak ez dituela lehenesten mozkin asmorik gabeko figura juridikoak dituzten enpresak, baizik eta tradizionalki hirugarren sektoreari lotu izan zaizkion praktikak egiaztatzen dituztenak, izan enpresa horiek mozkin asmorik gabekoak ala ez:

En principio está abierto a todo el mundo, pero hay, por un lado, requisitos de acceso y, por otro lado, medidas de discriminación positiva. Y tanto los requisitos de acceso como las medidas de discriminación positiva tienen que ver con prácticas que, a la postre, caracterizan, en mayor medida, habitualmente, no siempre, a las organizaciones del tercer sector. Pero no por una determinada figura jurídica, no por el hecho de tener carácter no lucrativo, de ser asociación, fundación..., sino prácticas, que también, si quisiera, podría garantizar una empresa. Por ejemplo, la reinversión del beneficio en la actividad. Eso es al final el carácter no lucrativo, pero no está asociado a la figura jurídica, sino a la práctica en sí. Y como ésa, muchas otras. Por ejemplo, la permanencia (C.1).

Diskriminazio positiboko neurrien aldekoen argudioak bildu ostean, aldeko argudioak baino zalantza gehiago dituztenenak jorratuko ditugu jarraian.

Herri-erakundeetako arduradunen aldetik ageri dira nagusiki zalantza gehien, mota horretako neurrien aurrean kontrakotasun argiko jarrerarik ez izan arren, diskriminazio horren nolakoa ondo arautu, definitu eta ikuskatu beharra aldarrikatzen da, eta mozkin asmorik ez izatea ezeren berme ez dela uste da: 
Habría que estudiar medida por medida. Pero yo creo que en prestación de servicios hay cuestiones más relevantes que la naturaleza jurídica de la entidad. Ésa es mi opinión. A mí no me parece que tenga que ser absolutamente determinante la forma jurídica de la entidad, sea, ponga en los estatutos que tenga ánimo de lucro o no; creo que hay factores más relevantes. Hay que hablar también de las condiciones laborales de las personas que trabajan; ha habido problemas laborales en entidades sin ánimo de lucro, importantes también. Hay que ver el tipo de servicio que se oferta, hay más cuestiones a ser tenidas en cuenta. Las solvencias también, es decir, tu cuando vas a prestar un servicio a través de una entidad con o sin ánimo de lucro, la solvencia de la entidad también es importante, porque claro, por aquello de no arrastrarte en su caída (A.2).

Mozkina asmorik eza baino garrantzitsuagoak diren aldagaiak ere aztertu behar lirateke hortaz, lan baldintzen egoera, zerbitzuaren kalitatea, erakundearen kaudimena:

Nosotros estamos hablando de que tiene que haber concurrencia, entonces, ¿en igualdad de condiciones? ¿En caso de empate? Por supuesto. Ningún problema. Pero tienes que demostrar que estás en situación de igualdad, o que no eres peor que otro, [que] eres capaz de prestar mejores servicios, con mayor implantación, con mayores programas; entonces, ahí se marcan una serie de criterios (A.3).

Aldagai teknikoei garrantzia handiagoa aitortzen zaie, logikoa denez, zerbitzua erosten dutenen partetik, herri-erakundeen aldetik, alegia. Nahiz eta orduan, hori izanik lehentasuna, eztabaida faltsu baten aurrean geundekeen beste zenbaiten iritzian:

[...] para nosotros ese artículo es falso. No hay dos empresas que tengan dos...vamos a ver. El que valora, nunca valora igualmente [...] es rarísimo que en un concurso se empate técnicamente, ¿por qué? Porque es la parte, digamos, de libre albedrío de los concursos, ¿no? Cuando un concurso tiene poco de económico y mucho de técnico, sabemos que va a haber una decisión política debajo. Por lo cual, el supuesto...supuesta garantía que da la ley del 2008 sobre, en caso de igualdad, darle al tercer sector nunca se convierte porque realmente lo que hay es una decisión de ya decidiré yo en la mesa de valoración a quién se la doy (C.3).

Antzeko terminoetan mintzo da herri-erakundeetako ordezkari bat ere, berdintasun teknikoaren ezintasuna aipatuz, eta beraz, legea ekilibrismo politikoko ariketa huts gisa interpretatzen du, diskriminazio positibo hori egiazki inoiz praktikan jarriko ez dela pentsatzen duelarik:

[...] eso de la igualdad técnica no existe. Es muy raro que dos ofertas se igualen en lo técnico.
Otra cosa es que tú inconscientemente valores mejor técnicamente una entidad sin ánimo de lucro, porque tú entiendas que es mejor y tal, y en la propia subjetividad de la valoración, hay un elemento subjetivo, pero igualdad técnica... yo todavía no he visto un concurso... Y al final se tira por vías intermedias, que no son ni una cosa ni la otra; entonces se quedan en declaraciones de intenciones, que a quien propone la ley le sirven, pues de una especie de bálsamo o lubricante moral, pero realmente dices "yo creo que había una intención de acotar la presencia de las entidades privadas en la prestación de servicios"; que otra contraparte decía que ni para Judas, o sea, que no quería esa limitación. Y dices “bien, vamos a llegar aquí a un[a] entente donde hay[a] un artículo que diga que, bueno, que en igualdad de condiciones se prime y tal". Hombre quien está en la otra contraparte interpreta que esa igualdad no se va dar nunca y que bueno, pues [es] una declaración de intenciones, nada más (A.2).

Beste eragile batzuentzat ordea, zinez ez da beharrezkoa halako neurri gehigarririk jartzea, jadanik lehenago existitzen direlako herri-erakundeen aldetik kontrolerako bestelako mekanismoak edo sektore hau bultzatzeko bestelako neurriak ere:

[...] si yo controlo la garantía de la atención desde la Administración, ¿por qué voy a hacer una discriminación positiva a través de una empresa sin ánimo de lucro? (B.3).

Bueno, nik eztet horren biharrezko ikusten. Guk kontrolauta baldin badakau pribatu hoiek ze marjenian barruan ibili bihar baldin badue, ba berdin zait, ikusi ezkeo ondo lana iten duela, eta teknikamente preparauta baldin badaude, zeatikan ez? Eztet uste horreatikan gehio baloratu bihar dala, edo puntu gehio eman behar zaiola, eztet uste. Inportantiena da técnicamente, darle el servicio al que técnicamente esté mejor preparado, aunque no sea una fundación (B.2).

E... ez dakit beharrezkoa zan. Aber, ez dakit egia esan ez dakit kontratazio legean dago, kontratazio legeak klausula sozialekin dituen aukerak erabilita, bai? [...] Orduan legeak egiten duen garapen guzti hori ez dakit beharrezkoa dan, ez dakit ze ekarriko digun (A.5).

Zalantzak ageri dira, hortaz, neurriaren egokitasunaz baina baita neurriaren aplikagarritasunaz ere. Zentzu horretan, neurria bere hastapenetatik oker planteatuta dagoela uste duenik ere bada, legearen atzean egiten diren zenbait erabilpen makur salatzen dituztelarik:

Sí, sí, hay empresas mercantiles que hacen fundaciones, y asociaciones sin ánimo de lucro. No voy a criticar pero, está claro que la fundación es no lucrativa, pero ya me gustaría a mí el sueldo que tiene el gerente de... [fundazio bat aipatzen du], porque claro, puede haber derivaciones todas las 
que quieras. 0 sea, no es lucrativa, pero por otro lado, pues te estás aprovechando de que al final los resultados los dejas donde los dejas a base de haber incrementado o de haber hecho el reparto de resultados de otra forma, ¿no? (B.5).

Nik usten det danok jokatzen ai geala nolabait partido berdina, ez? ai gea, konpetitzen ai gea eta esateizut asko izkutatzen dia larruazal horrekin [mozkin asmorik gabekoarekin] negozioak eiteko eta ordun ez nago konforme (B.7).

Legearen gainean egin litezkeen erabilpen makurren inguruan aldiz, legearen aldekoek gainditu beharreko albo-kalte gisa kontsideratuko dituzte horiek:

[...] baina es un mal menor, osea esan nahi det, ez baldin badezu hori jartzen legeetan, osea esan nahi det hori da bigilantzia gehiago jartzeko arrazoi bat, eta bueno horren kontsekuentzia bat, baina nik hori pasatzeko arriskua dagoelako ez nuke bestea egin gabe utziko, ez? (C.2).

Ése, sin duda, es un riesgo, ¿no? Lo que ocurre es que cualquier política o cualquier medida 0 cualquier decisión tiene riesgos; entonces, la obligación por parte del sector público es establecer los indicadores y los mecanismos para discriminar y separar el grano de la paja. Y la responsabilidad del propio tercer sector es la de autorganizarse, autorregularse y generar mecanismos para distinguir aquellos que realmente son tercer sector genuino y organizado y voluntario y etc., de aquellos que lo que hacen es hacer una utilización espuria de la fórmula jurídica (A.1).

\section{Ondorioak}

Bukatze aldera, eta orain arte azalduriko eztabaidak nolabait sintetizatu nahian, Euskadin egikaritzen ari den gizarte-zerbitzuen sistema mistoan zeharkako kudeaketarako dauden aukera ezberdinen artean gure posizioa azaldu aurretik, aurretiazko bi premisa, aurretiazko bi betekizun finkatu behar direla deritzogu.

Argi geratu zaigu marko teorikoaren analisian gure sistema Europako hegoaldeko herrialdeen eredu familiaristan kokatu behar litzatekeela nagusiki, nahiz eta eredu ezberdinetako zenbait ezaugarri ere badituen, beste herrialde guztiek bezalaxe. Baina bai gizarte-zerbitzuek izaniko garapen berantiar eta bukatu gabeagatik, bai familiak jokatzen duen nagusitasunezko paperagatik eta baita hirugarren sektoreak zenbait esparrutan agertzen duen parte hartze esanguratsuagatik ere, gure sistemak hegoaldeko ongizate-sistema rudimentarioen eitea ageri du.

Lehen betekizuna, hortaz, sistemaren izaera informala gainditzeko betebeharrean finkatu behar litzatekeela deritzogu. Honetan erradikalak izan beharra defendatzen dugu: berri emaile baten hitzak geure eginez, "emakumeen ikuspegitik hobe da gizartezerbitzuen sistema pribatizatu bat sistema informal bat baino". Asko dira sistema urpean edo informalitatean mantentzeak dakartzan ondorio ezkorrak: bai genero desberdintasuna areagotzen delako, bai herri-erakundeen aldetik zerbitzuen kalitatearen gaineko kontrol galera dakarrelako eta baita merkatu formal bat osatzeko zaintzen eskari potentziala uzkurtzen duelako ere. Agertoki hori, beraz, lehen lehenik gainditu beharreko elementutzat jotzen dugu. Nola irauli ordea sistemaren izaera informal hau?

Hemen ere erantzuna nahiko argia dela deritzogu: zerbitzu publikoak biderkatuz. Ez da egia zaintza lanak etxeguneetan emateak, mendeko pertsonen balizko lehentasun kultural bati erantzuten dionik. Zerikusi gehiago du, izatekotan, zaintzaileak, nagusiki emakumeak, sentitzen duen betebehar moral batekin. Ez da zuzena ere zaintzak etxeguneetan mantentzeak gertutasunezko sistema komunitarioa osatzen laguntzen duenik. Zaintza komunitarioa ez baita zaintza informala. Ez bakarrik, edo ez nagusiki. Zaintza komunitarioaren ereduak mendeko pertsona bere gertueneko paisaia eta harreman-sareetatik ez isolatzea bilatu asmo du. Baina zerbitzu publiko nahikorik eskaintzen ez den bitartean, argi dago komunitarismoa bultzatzeak emakumeen etxekotzea areagotzea baino ez dakarrela. Era berean, argi geratzen ari da zaintzen des-familiartze hau merkatuaren esku lagatzeak arazo ugari sortzen dituela, alde batetik ez delako kalitatezko eskaintza nahikorik sortzen ari, eta beste aldetik, zaintzak merkatuko logiken arabera emateak eskubide horretatik kanpo lagako lukeelako zaintza premian den pertsonen kopuru handi bat.

Aipaturiko elementu denek garamatzate portu berera. Gako nagusia zerbitzu publikoen biderkatzean datza. Horrek soilik berma lezake behar duen orok bere zaintza premiak asetzea. Legez gainera hala dago ezarria, gizarte-zerbitzuen esparrua erantzukizun publikoko esparru gisa finkatu baita, ez beraz erantzukizun informal, pribatu edo mistoko sektore gisa. Zerbitzu publikoen sistema nahikoak eta kalitatezkoak soilik lor dezake, halaber, erabiltzaileen ‘aukeratzeko aukera’ erreala izan dadin. Modu honetan, baliabide publikoen ondoan bestelako baliabide pribatu edo informalak uztartu nahi dituenak hartarako aukera leukake, baita baliabide publikoei muzin egiteko ere. Baina soilik orduan justifikatu ahal izango da sistemaren izaera publiko, pribatu edo informalagoa jendartearen aukera gisa, ez orain sarri askotan egiten den gisan, 'aukeratzeko aukera' errealik ez baita oraindik.

Aipaturiko bi horiek lirateke, hortaz, artikulu honetako eztabaidagaiaren aurretik ebatzi beharreko bi korapiloak: sistema informala urazaleratu beharra lehenik, eta horretarako sistema publiko kalitatezko eta nahikoa osatzea bigarrenik.

Behin bi baldintza horiek beteta, guk artikulu honetan planteaturiko galdera, sistemaren kudeaketa ereduari loturiko afera bat baino ez litzateke. 
Eta sistemaren kudeaketa eredua, adituen panelaren bitartez jorraturiko eztabaidan landu dugu. Eztabaida hori behar bezala jorratzeak eztabaidaren posizio sinplistei izkin egitea eskatzen du. Gure esparrurako gainera, gizarte-zerbitzuen etorkizuneko diseinuak jadanik kontsolidaturiko beste bi ongizate-sistemen erreferentziak kontuan hartu beharra dakarkigu: osasun sistema publikoa alde batetik, eta hezkuntza sistema itundua bestetik.

Osasun sistema publikoaren gain, eta oro har ongizate-estatuaren iraunkortasunaren gain azken aldian jazotzen ari garen presio izugarriko testuinguru batean, eredu publikoaren alde egitea korrontearen kontra jotzea begitanduko zaio askori. Guk ez dugu eredu hau inondik inora alboratu nahi. Argi duguna da eredu hau epe motzean erdiesteak zailtasun politiko eta ekonomiko garrantzitsuak leuzkakeela aurrean, akordio politiko zabalak lortu behar bailirateke zerbitzuon finantzazioari dagokionean eta baita lurralde egituraketari dagokionean ere, bi gai arantzatsu aipatzearren. Zailtasunak zailtasun, pentsa dezagun une batez bestelako ereduen alde jotzeak ere lituzkeen arazoetan.

Eredu itunduaren alde egitea da aukeretako bat, hezkuntza sisteman ezagutzen dugunaren pareko baten alde. Errealitateak ordea ez dira guztiz asimilagarriak, hezkuntza sistemaren baitan sare publikoaren aurretiazko sare pribatu oso indartsu bat ageri baita, ikastolek eta eskola erlijiotsuek osatua, hain zuzen ere. Gure iritzian, gizarte-zerbitzuen alorrak, eta zehazkiago pertsona nagusien azpisektoreak, ez du inondik inora halako lur ongarriturik agertzen esparru komunitarioarekin itunduriko sistema bat egikaritzeko.

Beste aukera bat pribatizazioaren bidetik jotzea da. Bide honen alde egiten dutenak sistemaren balizko eraginkortasun handiago baten aitzakiapean egiten dute. Gure iritzian, eragile pribatuek modu eraginkorrean funtziona dezaten zenbait merkatu baldintza eman behar dira, ekonomialariok 'lehia perfektuko balizkako' gisa izendatzen ditugunak: inork prezioan eragiteko ahalmenik ez izatea edo hornitzaile eta erosle txiki askok osatutako merkatuak izatea, besteak beste.

Baina balizkako horiek betetzetik oso urrun ageri dira merkatuok, prezioak neurri handi batean herrierakundeek finkatzen baitituzte eta era berean, administrazio publikoa baita mendekotasunaren legearen aginduz norbanakoen eskariak zentralizatu eta bideratzen dituena. Merkatu baldintza hauetan pribatizazioaren alde egiteak bestelako interesak ezkutatzen ditu gure iritzian, eta sakoneko errore bat azaleratzen: sistema eraginkorragoa sistema merkeagoa dela sinestea, hain zuzen ere. Eta hortik eratortzen dira gastu publikoa uzkurtzearen aldeko politika ekonomiko guztiak. Gure iritzian sistema eraginkorragoa ez da, alabaina, berdina merkeago eskaintzea lortzen duena, gutxiagorekin gehiago egitea lortzen duena baizik.

Eta estrategia honen baitan kokatzen dugu guk sektorea kooperatibizatzearen aldeko hautua. Zaintzen esparrua kooperatibizateak sistemaren diseinuaren bi afera nagusiri erantzuten lagun dezakeela iruditzen zaigu: alde batetik hirugarren sektorearen nora ezari zentzu berriak ematen lagun diezaioke, argi baitago erakundeok gero eta forma enpresarialagoak hartu beharrean aurkitzen direla, boluntarioen funtzio horiek albo batera utziz, bai zerbitzu publikoen hornikuntzan bederen.

Beste aldetik, herri-erakundeek sistemaren hedadura publikoa handitzeko baliatu dezaketen estrategiarik egokienetako bat izan liteke. Modu horretan, zerbitzu publikoen kudeaketan mozkin asmoa duten enpresa pribatuek jarduteak suposatzen duen kontraesan etikoa gainditzen da, kooperatibek mozkin asmoa izan arren, mozkinen trataera komunitarioagoa bermatzen baitute, baita mozkin asmorik gabeko erakundeek baino areago. Eta azken buruan, eredu gertuko eta komunitarioagoa erdiesteko bidean, erabiltzaileek, familiarrek zein herri-erakundeek enpresaren jardueraren gaineko kontrola izateko enpresa-egiturarik parte hartzaileenen aldeko hautua egiten da. 
ADELANTADO, J.; eta JIMÉNEZ, A. (2003): “Las políticas de servicios sociales de las Comunidades Autónomas", in GALLEGO, R.; GOMÁ, R.; eta SUBIRATS, J. (ed.), Estado de Bienestar y Comunidades Autónomas: la descentralización de las políticas sociales en España, Madril, Tecnos; Universitat Pompeu Fabra.

ADELANTADO, L. (koord.): Cambios en el Estado del Bienestar. Políticas sociales y desigualdades en España, Bartzelona, Icaria.

CASADO, D. (2007): “Apunte histórico de la construcción de los servicios sociales", in CASADO, D.; eta FANTOVA, F. (koord.), Perfeccionamiento de los servicios sociales en España: informe con ocasión de la Ley sobre autonomía y dependencia, Madril, Fundación Foessa, Cáritas.

DEL PINO, E.; eta RAMOS, J. A. (2009): “Las reformas de las políticas de bienestar en España: una visión de conjunto", in MORENO, L. (ed.): Reformas de la Políticas del Bienestar en España, Madril, Siglo XXI.

EHAA (2008): “12/2008 Legea, abenduaren 5ekoa, Gizarte Zerbitzuei buruzkoa", 246. zenb., 31.840-31.924 or. [khttp://www.euskadi.net/ bopv2/datos/2008/12/0807143a.pdf〉].

ESPING-ANDERSEN, G. (1999): Social Foundations of Postindustrial Economies, Oxford; New York, Oxford University Press.

FANTOVA, F. (2009): “Marco conceptual, normativo y estratégico para una política foral de servicios sociales en Gipuzkoa: hacia una comprensión, encaje y desarrollo de los servicios públicos en el ámbito de los servicios sociales", in GIZARTE POLITIKAKO DEPARTAMENTUA, Hausnarketa Prozesuaren Txostenak, Donostia, Gipuzkoako Foru Aldundia [<http://www.gizartepolitika.
net/proceso_reflexion/PONENCIAS/Marco_ Fernando\%2oFantova.rtf $>$.

GALLEGO, R.; GOMÁ, R.; eta SUBIRATS, J. (ed.) [2003]: Estado de Bienestar y Comunidades Autónomas: la descentralización de las políticas sociales en España, Madril, Tecnos; Universitat Pompeu Fabra.

IVAP (2006): 39/2006 Legea, abenduaren 14koa, autonomia pertsonala sustatzeari eta mendetasun-egoeran dauden pertsonak zaintzeari buruzkoa, Gasteiz, Herri Arduralaritzaren Euskal Erakundea.

MORENO, L. (ed.) [2009]: Reformas de la Políticas del Bienestar en España, Madril, Siglo XXI.

MORENO, L. (2002): “Bienestar mediterráneo y supermujeres”, Revista Española de Sociología, 2. zenb., 41-57 or.

NOGUERA, J. A. (2000): “Conclusiones. La reestructuración de la política social en España", in ADELANTADO, L. (koord.), Cambios en el Estado del Bienestar. Políticas sociales y desigualdades en España, Bartzelona, Icaria.

PÉREZ DE OROZCO, A. (2006): “Amenaza tormenta: la crisis de los cuidados y la reorganización del sistema económico", Revista de Economía Crítica, 5. zenb., 7-37 or.

RODRÍGUEZ CABRERO, G. (2004): El Estado del Bienestar en España: debates, desarrollo y retos, Madril, Editorial Fundamentos.

ROGERO GARCÍA, J. (2010): Los tiempos del cuidado. El impacto de la dependencia de los mayores en la vida cotidiana de sus cuidadores, bilduma: Estudios, saila: Dependencia, Madril, Imserso.

SANCHO, M. (zuz.) [2011]: Estudio sobre las condiciones de vida de las personas mayores de 60 años en la Comunidad Autónoma del País Vasco, ECVPM- 
Euskadi 2010, saila: Documentos de Bienestar Social-Gizartea Hobetuz, 74. zenb., VitoriaGasteiz, Eusko Jaurlaritza-Gobierno Vasco.

SARASA, S. (2000): "La última red de servicios personales", in ADELANTADO, L. (koord.), Cambios en el Estado del Bienestar. Políticas sociales y desigualdades en España, Bartzelona, Icaria.
SIIS-CENTRO DE DOCUMENTACIÓN Y ESTUDIOS / DOKUMENTAZIO ETA IKERKETA ZENTROA (2012): II Informe sobre la Situación de los Servicios Sociales en la CAPV, Vitoria-Gasteiz, Gizarte Zerbitzuen Euskal Kontseilua; Eusko JaurlaritzaGobierno Vasco.

ROLDÁN, E; eta GARCíA, T. (2006): Políticas de Servicios Sociales, Madril, Editorial Síntesis.

\section{Eranskina}

Elkarrizketaturiko adituen zerrenda, profilaren arabera

\begin{tabular}{|c|c|c|c|}
\hline Erakundea & Azpi-erakundea & Kodea & Ardura \\
\hline \multirow{5}{*}{$\begin{array}{l}\text { Herri-erakundetako } \\
\text { ordezkari } \\
\text { eta langileak }\end{array}$} & Eusko Jaurlaritza & A.1. & Erkidego mailako politikari goi-karguduna \\
\hline & \multirow{3}{*}{ Foru Aldundia } & A.2. & Foru Aldundi mailako politikari goi-karguduna \\
\hline & & A.3. & Foru Aldundi mailako teknikari goi-karguduna \\
\hline & & A.4. & Foru Aldundi mailako teknikari goi-karguduna \\
\hline & Udala & A.5. & Udal mailako teknikari goi-karguduna \\
\hline \multirow{7}{*}{$\begin{array}{l}\text { Gizarte ekonomiako } \\
\text { eragileak }\end{array}$} & \multirow{2}{*}{ Elkarteak } & B.1. & Elkarte profesionaleko arduraduna \\
\hline & & B.2. & Boluntario elkarteko zuzendaria \\
\hline & \multirow{2}{*}{ Fundazioak } & B.3. & Fundazio pribatuko arduraduna \\
\hline & & B.4. & Fundazio pribatuko zuzendaria \\
\hline & \multirow{3}{*}{ Kooperatibak } & B.5. & Kooperatibako koordinatzaile nagusia \\
\hline & & B.6. & Kooperatiben sustapenerako erakundeko arduraduna \\
\hline & & B.7. & Kooperatiben sustapenerako plataformako arduraduna \\
\hline \multirow{4}{*}{$\begin{array}{l}\text { Bestelako gizarte } \\
\text { eragileak }\end{array}$} & \multirow{2}{*}{$\begin{array}{l}\text { Gizarte Zerbitzuen alorreko } \\
\text { dokumentazio eta ikerketa zentroak }\end{array}$} & C.1. & Dokumentazio eta ikerketa zentroko arduraduna \\
\hline & & C.2. & Dokumentazio eta ikerketa zentroko arduraduna \\
\hline & Sindikatua & C.3. & Gizarte-zerbitzuen alorreko ordezkari sindikala \\
\hline & Mugimendu feminista & C.4. & Mugimendu feministako kidea \\
\hline
\end{tabular}

Iturria: Egileen lana. 